\title{
Mevcut konut türü betonarme bir binanın deprem güvenliğinin incelenmesi
}

\author{
Investigation of seismic safety of an existing residential $R C$ building
}

\author{
Oğulcan SARI ${ }^{1, a}$, Hakan ULUTAŞ ${ }^{* 2, b}$ \\ ${ }^{1}$ Inşaat Yüksek Mühendisi, 07080, Antalya
}

${ }^{2}$ Burdur Mehmet Akif Ersoy Üniversitesi, Mühendislik Mimarlık Fakültesi, İnşaat Mühendisliği Bölümü, 15030, Burdur

\begin{abstract}
• Geliş tarihi / Received: 31.03.2021• • Düzeltilerek geliş tarihi / Received in revised form: 12.07.2021 • Kabul tarihi / Accepted: 28.07 .2021
Öz

Bu çalı̧̧ada, mevcut yapı stokunun önemli bir bölümünü oluşturan konut türü betonarme bir binanın deprem güvenliği 2007 ve 2018 deprem yönetmeliklerine göre incelenmiş, elde edilen sonuçlar karşılaş̧ırıllmıştır. Kesitlerin moment eğrilik bağıntıları ile plastik mafsal özelliklerinin belirlenmesi ve statik itme analizleri SAP 2000 yazılımında gerçekleştirilmiştir. Yapılan çözümlerde; yönetmeliklere göre kesit şekil değiş̧irme üst sınırlarında, doğal titreşim periyotlarında, hedef yer değiştirme istemlerinde, taşıyıcı sistem elemanlarında oluşan hasarlarda ve katların performans düzeylerinde farklı sonuçlar elde edilmiştir. İncelenen bina her iki yönetmeliğe göre de $\mathrm{x}$ - doğrultusunda hedef performans seviyesini sağlayamamış, $\mathrm{y}$ - doğrultusunda hedef performans seviyesini sağlayabilmiştir.
\end{abstract}

Anahtar kelimeler: DBYBHY-2007, Doğrusal elastik olmayan yöntem, Performans analizi, TBDY-2018, Tek modlu statik itme analizi

\begin{abstract}
In this study, the earthquake safety of a residential type reinforced concrete building, which constitutes a significant part of the existing building stock, was examined according to the 2007 and 2018 earthquake codes, and the results were compared. Moment curvature relations of the sections, determination of plastic hinge properties and pushover analyzes were performed in SAP 2000 software. The analysis yielded varying results in terms of the upper limits of cross-sectional deformation, natural periods of structure, target displacement demands, damage to the structural system elements and performance levels of the floors. The examined building could not achieve the target performance level in the $x$-direction, but could achieve the target performance level in the y-direction according to both codes.
\end{abstract}

Keywords: TSC-2007, Nonlinear method, Performance analysis, TBEC-2018, Single mode pushover analysis

\footnotetext{
${ }^{* b}$ Hakan ULUTAŞ; hakannulutas@gmail.com, Tel: (0246) 21327 46, orcid.org/0000-0003-1721-7268

${ }^{\text {a }}$ orcid.org/0000-0002-8928-9124
} 


\section{Giriş}

Türkiye ve yakın çevresinin önemli deprem felaketlerinin yaşandığ 1 ve tektoniği aktif olan bir bölgede olmasindan dolayı, bölgede depremselliğin izlenmesi, kayıt altına alınması ve bilimsel olarak irdelenmesi büyük önem arz etmektedir (Yalçın vd., 2013). Özellikle son yıllarda dünyada ve ülkemizde yaşanan yıkıcı depremlerin sebep olduğu büyük çaplı can ve mal kayıpları, deprem konusunda yapılan çalışmaları, araştırmaları ve alınacak önlemlerin önemini gündeme getirmiştir (Işık, 2013). Depremde meydana gelen can ve mal kayıları düşünüldüğünde en önemli ihtiyaçlarımızdan birinin depreme karşı güvenli yapılar inşa etmek olduğu söylenebilir (Dilmaç vd., 2013). Ülkemizde depreme karşı dayanıklı yapı inşa etmek amacıyla 1940 yılından günümüze 10 farklı deprem yönetmeliği kullanılmıştır. Her yeni çıkan yönetmelik bir önceki yönetmelikte görülen eksiklerin giderilmesi doğrultusunda yapılmıştır. Ülkemizde 2007 ile 2019 tarihleri arasında Deprem Bölgelerinde Yapılacak Binalar Hakkında Yönetmelik (DBYBHY, 2007) kullanılmaktaydı. 1 Ocak 2019 tarihi itibariyle ise Türkiye Bina Deprem Yönetmeliği (TBDY, 2018) kullanılmaya başlanmıştır. Deprem yönetmeliğinin güncellenmesiyle birlikte meydana gelen değişikliklerin binalar üzerindeki etkisi araştırılmaya başlanmıştır (Tunç ve Tanfener, 2016; Demir ve Kayhan, 2017; Başaran, 2018; Dilmaç vd., 2018; Keskin ve Bozdoğan, 2018; Koçer vd., 2018; Asığçel, 2019; Gündoğay vd., 2019; Engin, 2019; Kadaş vd., 2019; Karaca, 2019; Kılıç, 2019; Soycan, 2019; Topaktaş, 2019; Uçar, 2019; Ulutaş, 2019; Aksoylu vd., 2020; Işık vd., 2020; Karaca vd., 2020; Karaca, 2020; Karasin vd., 2020; Şimşek, 2020; Turan, 2020; Aksoylu vd, 2021; Işı1k vd., 2021; İbiş ve Ulutaş, 2021; Yalın ve Ulutaş, 2021). Literatürde yapılan çalışmalarda, 2007 ve 2018 deprem yönetmelikleri genel bağlamda yapısal tasarım, kesit hasar sınırları, deprem performans1, taban kesme kuvveti, bina tepe yer değiştirmesinde meydana gelen değişim ve binaların sismik davranış özellikleri gibi konularda kıyaslanmıştır.

Deprem yönetmeliğinin değişmesiyle birlikte mevcut binaların deprem güvenliğinin belirlenmesi için gerekli olan malzeme gerilme şekildeğiştirme bağıntılarında, kesit hasar sınırlarında, kesit hasar bölgelerinde, kesit şekildeğiştirme üst sınırlarında, etkin kesit rijitliklerinde, elastik spektrum eğrisinde, performans düzeylerinde, bina performans düzeyinin belirlenmesi için taşıyıcı elemanların sağlaması gereken koşullarda ve hedef performans düzeylerinde değişikliklere gidilmiştir. DBYBHY ve TBDY yönetmeliklerinin ikisine göre de statik itme analizi yapılmadan önce statik düşey yüklerin taşıyıcı sisteme artımsal olarak uygulandığ 1 doğrusal olmayan statik hesap yapılması gerekmektedir. TBDY'e göre statik düşey yükler hesabında düşey deprem etkisi dikkate alınırken, DBYBHY'de bu etki dikkate alınmamaktaydı. Ayrıca DBYBHY ile yalnızca mevcut binalarının deprem güvenliği belirlenebilmekteydi. TBDY ile mevcut binalar ile birlikte yeni yapılacak binaların da depreme karşı güvenliği belirlenebilmektedir. Mevcut binaların depreme karş1 güvenliği belirlenirken beton ve donatının mevcut dayanımları kullanılmakta, yeni yapılacak binalarda ise beklenen ortalama dayanımlar kullanılmaktadır. Ayrıca yeni yapılacak binalarda etkin kesit rijitlik çarpanlarının belirlenmesi için kesitlerin moment eğrilik analizlerinin yapılması gerekmektedir. Kesitlerin etkin kesit rijitlik çarpanları, yapılan bu analizlerden elde edilen plastik mafsallarının etkin akma momentleri ve etkin akma eğrilikleri kullanılarak belirlenmektedir.

$\mathrm{Bu}$ çalışmada, Burdur ilinde bulunan, Afet Bölgelerinde Yapılacak Yapılar Hakkında Yönetmelik (ABYYHY, 1998) esaslarına göre tasarlanmış ve 2004 yılında inşa edilmiş mevcut konut türü betonarme bir binanın proje verileri temin edilmiştir. Taşıyıcı sistemi yalnızca çerçevelerden oluşan 4 katlı bu binanın DBYBHY ve TBDY deprem yönetmeliklerine göre deprem güvenliği incelenmiş, elde edilen performans sonuçları birbiri ile karşılaştırılmıştır. Bunun için mevcut binanın DBYBHY ve TBDY esaslarına göre SAP 2000 programında modelleri oluşturulmuştur. Her iki yönetmeliğine göre malzeme gerilme şekil değiştirme bağıntıları, kesitlerin şekildeğiştirme üst sınırları, etkin kesit rijitlikleri, hedef yerdeğiştirme istemleri, taşıyıcı elemanlarda oluşan hasarlar ve katların performans düzeyleri belirlenmiştir. Söz konusu bu işlemler excel formatında hazırlanan bir dosyadan faydalanılmıştır. Kesitlerin moment eğrilik bağıntıları ile plastik mafsal özelliklerinin belirlenmesinde SAP 2000'in "Section Desinger" arayüzünden faydalanılmıştır. DBYBHY'e göre yapılan analizlerde doğrusal elastik olmayan değerlendirme yöntemlerinden artımsal eşdeğer deprem yükü yöntemi, TBDY'e göre yapılan analizlerde ise doğrusal elastik olmayan değerlendirme yöntemlerinden sabit tek modlu itme analizi kullanılmıştır. 


\section{Binaların deprem performansının belirlenmesi}

DBYBHY ve TBDY deprem yönetmeliklerinin her ikisinde de binaların deprem performans seviyelerinin belirlenmesi için doğrusal elastik ve doğrusal elastik olmayan olmak üzere 2 hesap yöntemi önerilmektedir. Doğrusal ve doğrusal olmayan hesap yöntemlerinin alt yöntemleri bulunmaktadır. Bu çalışmada, DBYBHY'e göre yapılan analizlerde doğrusal elastik olmayan değerlendirme yöntemlerinden artımsal eşdeğer deprem yükü yöntemi, TBDY'e göre yapılan analizlerde ise artımsal eşdeğer deprem yükü yönteminin bu yönetmelikteki karşıllı̆̆ olan sabit tek modlu itme yöntemi kullanılmıştır. TBDY'de Artımsal eşdeğer deprem yükü yöntemi yerine sabit tek modlu itme yöntemi ifadesi kullanmıştır. Her iki itme yönteminde de, göz önüne alınan deprem doğrultusunda her bir itme adımında katlara etkiyen deprem yükü artımları, deprem dışı yüklemelerden sonraki birinci adımda belirlenen ve itme hesabı boyunca hiç değiştirilmeyen sabit mod şekli ile orantılı olarak tanımlanmaktadır. Yapılan itme analiziyle eksenleri çatı katı yerdeğiştirmesi - taban kesme kuvveti olan kapasite eğrisi elde edilir. Kapasite eğrisine uygulanan koordinat dönüşümü ile eksenleri modal yerdeğiştirme - modal sözde-ivme olan modal kapasite diyagramı elde edilir. Modal kapasite eğrisi, tanımlanan deprem etkisi altında modal yerdeğiştirme talebinin ve buna bağlı olarak taşıyıcı sistemde meydana gelen iç kuvvet ve plastik şekildeğiştirme taleplerinin hesaplanmasında esas alınır (TBDY, 2018).

\subsection{Kesit hasar sinırları ve hasar bölgeleri}

DBYBHY ve TBDY deprem yönetmeliklerinin her ikisinde de sünek elemanlar için kesit düzeyinde üç hasar durumu ve hasar sınırı tanımlanmıştır. DBYBHY'de bu hasarlar Minimum Hasar Sinırı (MN), Güvenlik Sınırı (GV) ve Göçme Sınırı (GÇ) iken, TBDY'de Sinırlı Hasar (SH), Kontrollü Hasar (KH) ve Göçme Öncesi Hasar (GÖ)'dır. Yapılan doğrusal olmayan analiz sonucu kesitlerde meydana gelen şekil değiştirmelerin Tablo 1'de ilgili yönetmelik için verilen birim şekildeğiştirme sınırları ile karşılaştırılması sonucunda kesit hasarı belirlenmiş olur.

Tablo 1. Kesit hasar sınırlarına göre izin verilen şekildeğiştirme üst sınırları

\begin{tabular}{ccc|cc}
\hline \multicolumn{1}{c|}{ DBYBHY } & TBDY \\
\hline $\begin{array}{c}\text { Kesit } \\
\text { hasar } \\
\text { sinırı }\end{array}$ & $\begin{array}{c}\text { Beton şekildeğiştirme } \\
\text { üst sınırları }\end{array}$ & $\begin{array}{c}\text { Donatı çeliği } \\
\text { şekildeğiştirme } \\
\text { üst sinırları }\end{array}$ & $\begin{array}{c}\text { Kesit } \\
\text { hasar } \\
\text { sinırı }\end{array}$ & Plastik dönme üst sinırları $\left(\theta_{p}\right)$ \\
GÇ & $\begin{array}{c}\left(\varepsilon_{\mathrm{cg}}\right)=0.004+0.014 \\
\left(\rho_{\mathrm{s}} / \rho_{\mathrm{sm}}\right) \leq 0.018\end{array}$ & $\left(\varepsilon_{\mathrm{s}}\right)=0.060$ & $\mathrm{GÖ}$ & $\theta_{\mathrm{p}}^{(\mathrm{GÖ})}=\frac{2}{3}\left(\left(\phi_{\mathrm{u}}-\phi_{\mathrm{y}}\right) L_{\mathrm{p}}\left(1-0.5 \frac{L_{\mathrm{p}}}{L_{\mathrm{s}}}\right)+4.5 \phi_{\mathrm{u}} d_{\mathrm{b}}\right)$ \\
$\mathrm{GV}$ & $\begin{array}{c}\left(\varepsilon_{\mathrm{cg}}\right)=0.0035+0.01 \\
\left(\rho_{\mathrm{s}} / \rho_{\mathrm{sm}}\right) \leq 0.0135\end{array}$ & $\left(\varepsilon_{\mathrm{s}}\right)=0.040$ & $\mathrm{KH}$ & $\theta_{\mathrm{p}}^{(\mathrm{KH})}=0.75 \theta_{\mathrm{p}}^{(\mathrm{GÖ})}$ \\
$\mathrm{MN}$ & $\left(\varepsilon_{\mathrm{cu}}\right)=0.0035$ & $\left(\varepsilon_{\mathrm{s}}\right)=0.010$ & $\mathrm{SH}$ & $\theta_{\mathrm{p}}^{(\mathrm{SH})}=0$ \\
\hline
\end{tabular}

Burada; $\varepsilon_{\mathrm{cu}}$, kesitin en dış lifindeki beton basınç birim şekildeğiştirmesini; $\varepsilon_{\mathrm{cg}}$, etriye içindeki bölgenin en dış lifindeki beton basınç birim şekildeğiştirmesini; $\varepsilon_{\mathrm{s}}$, donatı çeliği birim şekildeğiştirmesini; $\rho_{\mathrm{s}}$, kesitte mevcut bulunan enine donatının hacimsel oranını; $\rho_{\mathrm{sm}}$, DBYBHY'e göre kesitte bulunması gereken enine donatının hacimsel oranını; $\phi_{\mathrm{u}}$, kesitteki göçme öncesi toplam eğriliği; $\phi_{y}$, plastik mafsal kesitindeki etkin akma eğriliğini; $L_{s}$, kesme açıklığını; $L_{\mathrm{p}}$, plastik mafsal boyunu; $d_{\mathrm{b}}$, ise düğüm noktasındaki donatıların ortalama çapını ifade etmektedir.

Elemanın kritik kesitlerinin hasarına bakılarak hangi hasar bölgesinde kaldığına karar verilir. DBYBHY'de verilen hasar sinırları ve hasar bölgeleri Şekil 1.a'da, TBDY'de verilen hasar sınırları ve hasar bölgeleri Şekil 1.b'de verilmiştir.

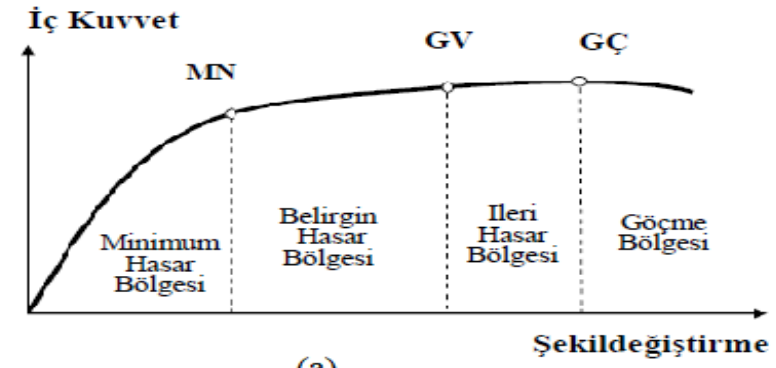

(a)

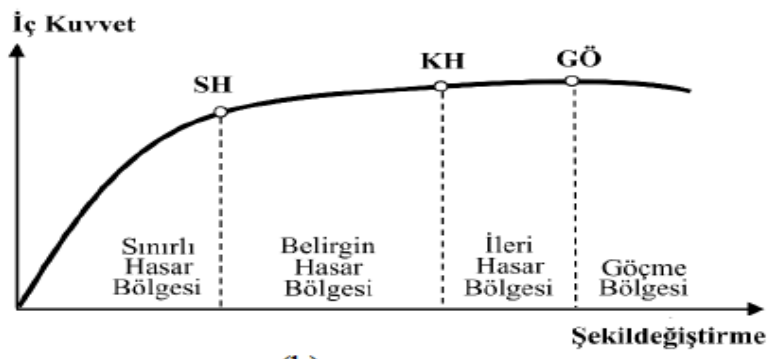

(b) 


\subsection{Bina performans düzeyleri}

DBYBHY'de Hemen Kullanım (HK), Can Güvenliği (CG) ve Göçme Öncesi (GÖ) olmak üzere 3 performans düzeyi verilmiştir. TBDY'de ise Kesintisiz Kullanım (KK), Sinırlı Hasar (SH), Kontrollü Hasar $(\mathrm{KH})$ ve Göçmenin Önlenmesi (GÖ) performans düzeyi olmak üzere 4 performans düzeyi bulunmaktadır. Her iki yönetmelikte de, verilen performans düzeylerinden herhangi birini sağlayamayan binalar Göçme Durumu'ndadır. DBYBHY ve TBDY yönetmeliklerinin ikisinde de kullanım amacına göre binanın sağlaması gereken minimum performans düzeyleri verilmiştir. Çalışma kapsamında mevcut konut türü bir bina incelenmektedir. Mevcut konut türü bir bina DBYBHY'e göre 50 yılda aşılma olasıllı̆g $1 \% 10$ olan depremler için $\mathrm{CG}$ hedef performans seviyesini, TBDY'e göre ise 50 yılda aşılma olasılığ1 \%10 olan depremler için $\mathrm{KH}$ hedef performans seviyesini sağlaması gereklidir. Binanın DBYBHY ve TBDY yönetmeliklerinde verilen hedef performans seviyesini sağlaması için taşıyıcı elemanlarının Tablo 2'de verilen koşulları sağlaması gerekmektedir.

Tablo 2. Minimum hedef performans seviyesi için taşıyıcı elemanların sağlaması gereken koşullar

\begin{tabular}{|c|c|c|}
\hline $\begin{array}{c}\text { Performans } \\
\text { seviyesi }\end{array}$ & Koşul & $\begin{array}{c}\text { Yönetmelik } \\
\text { maddesi }\end{array}$ \\
\hline CG & $\begin{array}{l}\text { (a) Herhangi bir katta, uygulanan her bir deprem doğrultusu için yapılan hesap sonucunda, ikincil } \\
\text { kirissler hariç olmak üzere, kirişlerin en fazla \%30'u Illeri Hasar Bölgesi'ne geçebilir. } \\
\text { (b) Illeri Hasar Bölgesi'ndeki kolonların, her bir katta kolonlar tarafindan taşınan kesme kuvvetine } \\
\text { toplam katkısı normal katlarda \%20'nin altında, en üst katta ise en fazla \%40 olmalıdır. } \\
\text { (c) Göçme bölgesine geçen kolon olmamalı ve herhangi bir katta alt ve üst kesitlerinin ikisinde } \\
\text { birden Minimum Hasar Sinırı aşılmışolan kolonlar tarafindan taşınan kesme kuvvetlerinin, o kattaki } \\
\text { tüm kolonlar tarafindan taşınan kesme kuvvetine oranı en fazla \%30 olmalıdır. }\end{array}$ & $\begin{array}{c}D B Y B H Y \\
7.7 .3\end{array}$ \\
\hline $\mathrm{KH}$ & $\begin{array}{l}\text { (a) Herhangi bir katta, uygulanan her bir deprem doğrultusu için yapılan hesap sonucunda, ikincil } \\
\text { kirişler hariç olmak üzere, kirişlerin en fazla \%35'i İleri Hasar Bölgesi'ne geçebilir. } \\
\text { (b) Illeri Hasar Bölgesi'ndeki düş̧ey elemanların, her bir katta düşey elemanlar tarafindan taşınan } \\
\text { kesme kuvvetine toplam katklsı normal katlarda \%20'nin altında, en üst katta ise en fazla \% } 40 \\
\text { olmalıdır. } \\
\text { (c) Göçme bölgesine geçen düşey elemanlar olmamalı ve herhangi bir katta alt ve üst kesitlerinin } \\
\text { ikisinde birden Belirgin Hasar Sinırı aşlmış olan düşey elemanlar tarafindan taşınan kesme } \\
\text { kuvvetlerinin, o kattaki tüm düşey elemanlar tarafindan taşınan kesme kuvvetine oranı en fazla \%30 } \\
\text { olmalıdır. }\end{array}$ & $\begin{array}{l}T B D Y \\
15.8 .4\end{array}$ \\
\hline
\end{tabular}

Tablo 1'de verilen koşullara gevrek olarak hasar gören elemanlar dâhil edilmezler. Gevrek olarak hasar gören elemanların güçlendirmeleri gerekmektedir.

\section{Mevcut konut türü betonarme bir binanın DBYBHY ve TBDY'e göre deprem performansının belirlenmesi}

$\mathrm{Bu}$ çalışmada, mevcut konut türü betonarme bir bina incelenmiştir. Bina, Burdur ilinde bulunmakta olup ABYYHY esaslarına göre tasarlanmış ve 2004 y1lında inşa edilmiştir. Bina $\mathrm{x}$ - doğrultusuna göre simetrik olup, $y$ - doğrultusunun bir tarafi bitişik nizamdadır. Binanın taşıyıcı sistemi her iki doğrultuda sadece çerçevelerden oluşmakta olup, her bir katta 18 adet kolon bulunmaktadır. Binanın kolonlarının kesit boyutları ve donatı düzenleri temel seviyesinden en üst kata kadar değişmeden devam etmektedir. İncelenen binanın genel özellikleri Tablo 3'te, zemin kat kalıp planı ise Şekil 2'de verilmiştir.

Tablo 3. İncelene binanın genel özellikleri

\begin{tabular}{ccc}
\hline $\begin{array}{c}\text { Bina kullanım } \\
\text { amacı }\end{array}$ & Konut \\
\hline Kat adeti & & 4 \\
Kat yüksekliği & & $3 \mathrm{~m}$ \\
Yap1 oturum alanı & & $117.37 \mathrm{~m}^{2}$ \\
Beton sinıfi & & $\mathrm{C} 20$ \\
Donatı sinıfi & & $\mathrm{S} 420$ \\
\hline Yerel Zemin sinıfi & DBYBHY & TBDY \\
Deprem bölgesi & 1 & ZE \\
SDS & - & - \\
SD1 & & 1.093 \\
\hline & & 0.716 \\
\hline
\end{tabular}




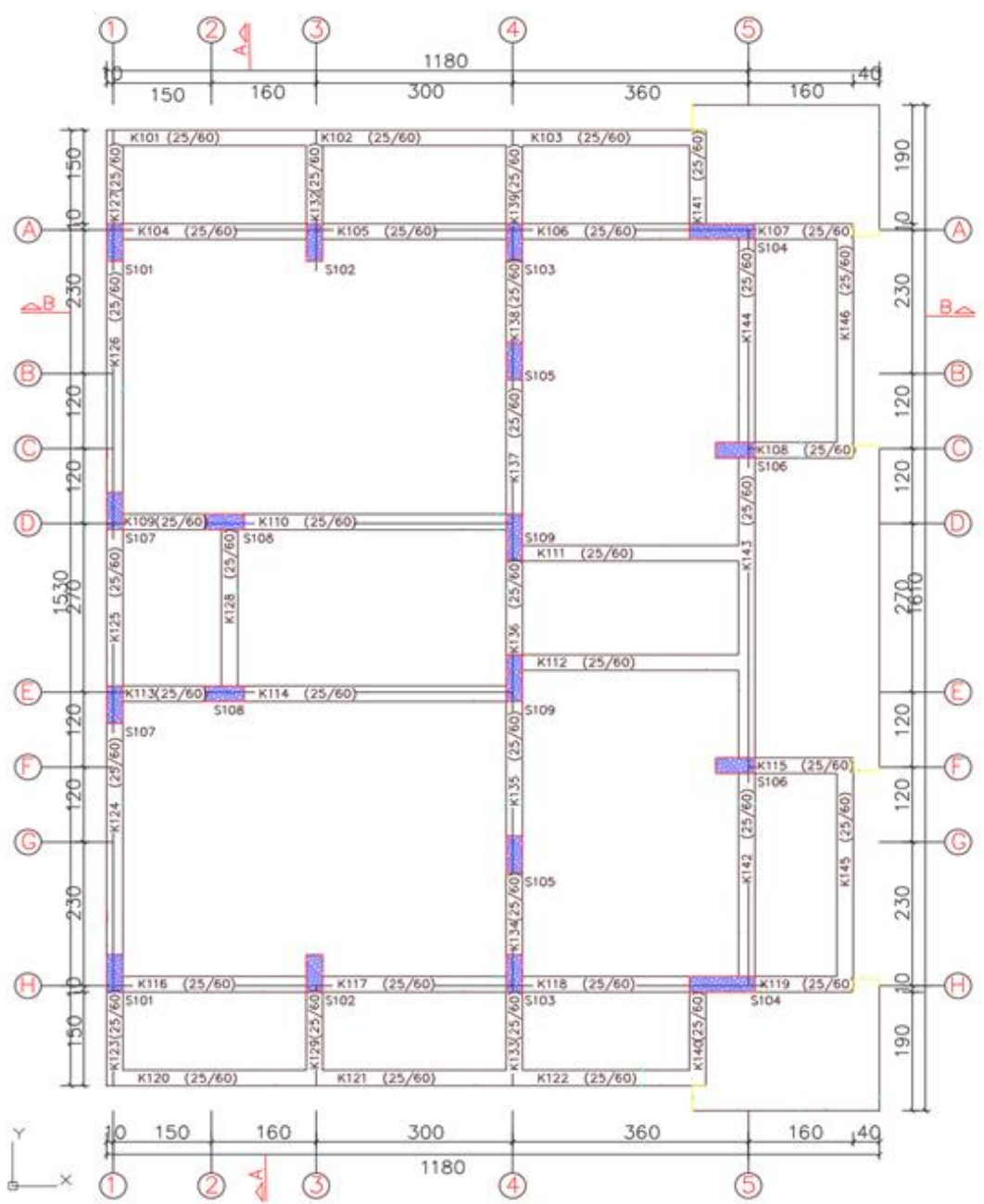

Şekil 2. Zemin kat kalıp planı

Tablo 4. Kiriş boyuna donatıları

\begin{tabular}{ccc}
\hline Kiriş ad1 & Üst donat1 & Alt donat1 \\
\hline K101-102-103-109-110-111-112-113-114-120-142-143-144-145-146 & $2 \emptyset 12$ & $3 \emptyset 12$ \\
K104-105-106-107-116-117-118-119 & $3 \emptyset 12$ & $2 \emptyset 12$ \\
K108-115-123-124-125-126-127-129-132-133-134-135-136-137-138-139-140-141 & $2 \emptyset 12$ & $2 \emptyset 12$ \\
K201-202-203-208-209-210-211-216-217-218-224-239-240 & $2 \emptyset 12$ & $3 \emptyset 12$ \\
K206-207-212-213- & $3 \emptyset 12$ & $2 \emptyset 12$ \\
K215-219-220-221-222-223-225-226-227-228-229-230-231-232-233-234-235-236-237 & $2 \emptyset 12$ & $2 \emptyset 12$ \\
K205-214-238 & $2 \emptyset 12$ & $5 \emptyset 14$ \\
\hline
\end{tabular}

Binadaki kolon kesitleri, boyut ve donatı düzeni bakımından incelendiğinde 4 çeşit kolon bulunmaktadır. Kolon kesitlerinin tamamında sıklaştırma bölgelerinde $10 \mathrm{~cm}$ arayla etriye bulunmaktadır. S101, S102, S103, S105, S107 kolonlarının kesitleri Șekil 3.a'da, S104 kolonun kesiti Şekil 3.b'de, S106 ve S108 kolonlarının kesitleri Şekil 3.c'de, S109 kolonunun kesiti ise Şekil 3.d'de verilmiştir. Şekilde verilen kesit boyutları $\mathrm{cm}$ cinsindendir. 


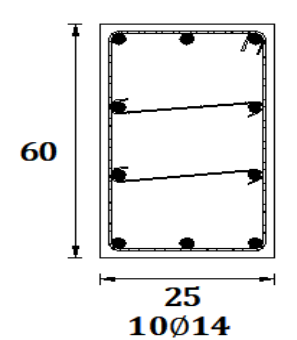

(a)

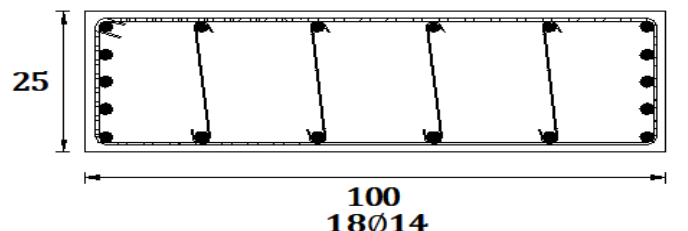

(b)

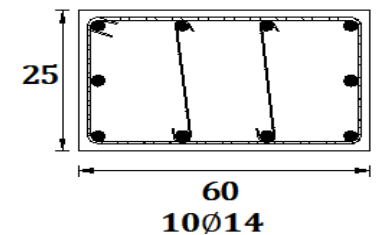

(c)

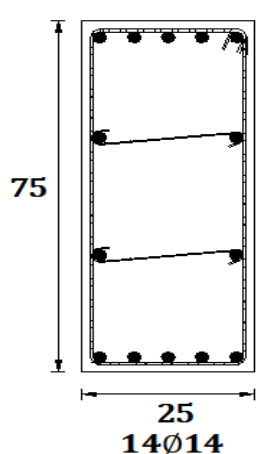

(d)

Şekil 3. Kolon kesitleri

\subsection{Bina taşıyıcı sisteminin modellenmesi}

İncelenen konut türü binanın 3 boyutlu modeli SAP2000 V20 programı ile modellenmiştir (Şekil 4).

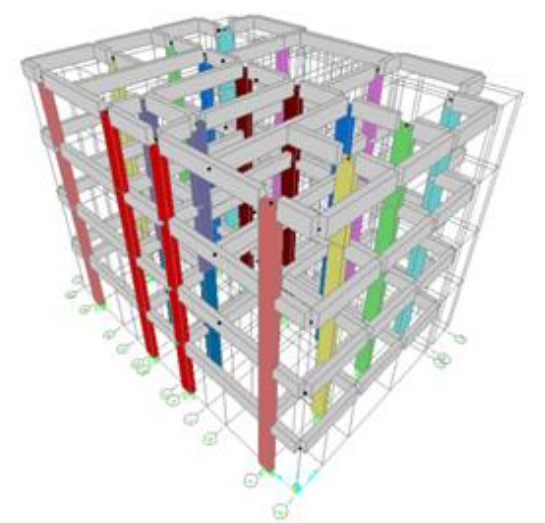

Şekil 4. Binanın 3 boyutlu SAP 2000 modeli

Modellerde kullanılan düşey yükler aşağıda verilmiştir.

- Döşeme sıva+ kaplama yükü= $\underline{1.5 \mathrm{kN} / \mathbf{m}^{2}}$

- Döşeme ölü yükü $=\gamma^{*} \mathrm{~h}_{\mathrm{f}}=25^{*} 0.15=\underline{\mathbf{3 . 7 5} \mathbf{~ k N} / \mathbf{m}^{2}}$

- İç ve dış duvar yükleri( sıva dahil) $=\underline{\mathbf{5} \mathbf{~ k N} / \mathbf{m}^{2}}$

- Döşeme hareketli yükü:

Normal döşemelerde: $\underline{\mathbf{~ k N} / \mathbf{m}^{2}}$

Balkon döşemelerinde: $\underline{\underline{\mathbf{5 k N} / \mathbf{m}^{2}}}$
Betonarme taşıyıcı sistem elemanlarının kesit özelliklerinin tanımlanmasında etkin kesit rijitlikleri kullanılmıştır. Etkin kesit rijitlikleri çarpanları DBYBHY ve TBDY yönetmeliklerinde farklılık göstermektedir. Kirişlerin etkin kesit rijitlik çarpanı DBYBHY esaslarına göre oluşturulan SAP 2000 modelinde 0.4, TBDY esaslarına göre oluşturulan SAP 2000 modelinde ise 0.35 alınmıştır. Kolonlar için belirlenen etkin kesit rijitlik çarpanları Şekil 5'te verilmiştir.

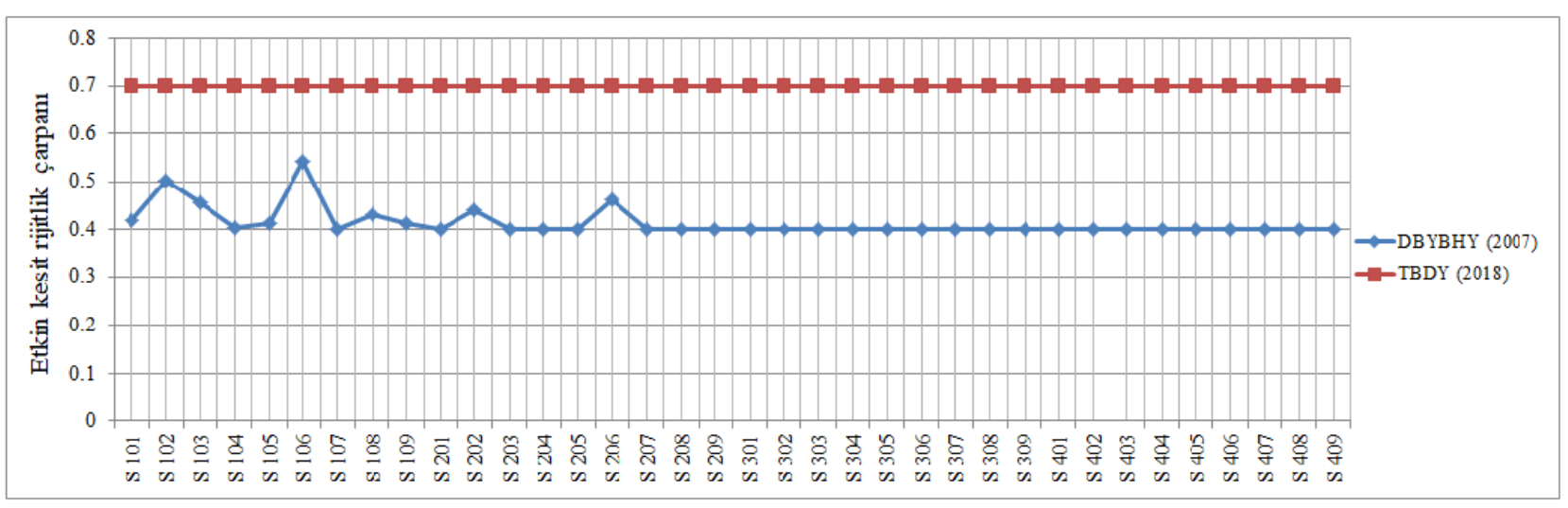

Şekil 5. Kolonlar için belirlenen etkin kesit rijitlik çarpanları 
Binanın deprem performans1, DBYBHY ve TBDY yönetmeliklerinin her ikisine göre de doğrusal olmayan değerlendirme yöntemi ile belirlenmiştir. DBYBHY'e göre yapılan analizlerde artımsal eşdeğer deprem yükü yöntemi, TBDY'e göre yapılan analizlerde ise sabit tek modlu itme analizi kullanılmıştır. İtme analizlerinde yapılan kabuller aşağıda sıralanmıştır.

- Binanın taşıyıcı sistemini oluşturan kolon ve kirişelerde doğrusal olmayan davranış modeli olarak yığılı plastik davranış modeli kullanılmıștır.

- Meydana gelen plastik şekil değiştirmelerin düzgün yayılı biçimde oluştuğu kabul edilmiştir. Plastik mafsal boyu olarak adlandırılan plastik şekildeğiştirme bölgesi'nin uzunluğu $\left(\mathrm{L}_{\mathrm{p}}\right)$, çalışan doğrultudaki kesit boyutu (h)'nin yarısına eşit alınmıştır.

- Plastik mafsallar kolon ve kirişlerin birleşim bölgelerinin dışına yani kolon ve kiriş net açıklık uç noktalarına konulmuştur.

- Kirişlerde plastikleşmenin tek eksenli eğilme momenti (M3) ile, kolon ve perdelerde ise iki eksenli eğilme momenti ve normal kuvvetin etkileşimi (P-M2-M3) ile meydana geldiği kabul edilmiştir.

- Kesme açıklığı (Ls), kolon ve kirişlerde açıklığın yarısı olarak alınmıştır.

\subsection{Kullanilan itme yöntemlerinin kullanılabilirliğinin kontrolü}

Artımsal eşdeğer yükü yöntemi ve sabit tek modlu itme yöntemlerinde binaya yalnızca hakim titreşim mod şekli ile kuvvet uygulanmaktadır. Bu yüzden bu yöntemlerle elde edilecek sonuçların tutarlı olabilmesi için TBDY ve DBYBHY'de binanın burulma düzensizliği katsayısı, modal kütle katılım oranı ve kat âdetinin sağlaması gereken koşullar bulunmaktadır. Bu koşullar ve incelenen binanın bu koşulara göre kıyası maddeler halinde aşağıda sıralanmıştır.

TBDY'ye göre $\mathbf{S}_{\mathbf{D S}}$ değeri 0.5'den büyük olan bir binanın yüksekliğinin 28 metreyi aşmamas1 gerekir. DBYBHY ise bina en fazla 8 katlı olabilmektedir. İncelenen bina 4 katlı olup yüksekliği 12 metredir. İncelenen bina her iki yönetmeliğinin bu koşulunu sağlamaktadır.

$>$ TBDY ve DBYBHY'in her ikisinde de modal kütle katılım oranı ile ilgili koşul aynı olup, bu koşula göre; göz önüne alınan deprem doğrultusunda, doğrusal elastik davranı̧̧ esas alınarak hesaplanan birinci (hakim) titreşim moduna ait etkin kütlenin toplam bina kütlesine (rijit perdelerle çevrelenen bodrum katlarının kütleleri hariç) oranının en az 0.70 olmas1 gerekmektedir. DBYBHY esaslarına göre oluşturulan modelde $\mathrm{X}$ ve $\mathrm{Y}$ hesap doğrultusu için model kütle katılım oranları sirasiyla 0.79 ve 0.76 ; TBDY esaslarına göre olușturulan modelde ise 0.783 ve 0.753 olarak elde edilmiştir. İncelenen bina her iki yönetmeliğinin bu koşulunu sağlamaktadır.

- TBDY ve DBYBHY'in her ikisinde de burulma düzensizliği katsayısı ile ilgili koşul aynı olup, bu koşula göre; herhangi bir katta ek dış merkezlik göz önüne alınmaksızın doğrusal elastik davranış esas alınarak hesaplanan burulma düzensizliği katsayısının

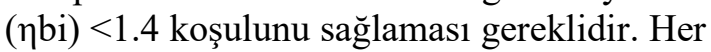
iki yönetmelik esaslarına göre oluşturulan modellerde tüm katlar için burulma düzensizliği katsayıları elde edilmiş, 4 kat için elde edilen değerin en büyüğü bina burulma düzensizliği katsayısı olarak belirlenmiştir. DBYBHY esaslarına göre oluşturulan modelde burulma düzensizliği katsayısı 1.35, TBDY esaslarına göre oluşturulan modelde ise 1.33 olarak elde edilmiştir. İncelenen bina her iki yönetmeliğinin bu koşulunu sağlamaktadır.

\subsection{Kesitlerin plastik mafsal özelliklerinin tanımlanmasl}

İncelenen binadaki her bir kesitin hasarını elde edebilmek için kesitlerin yığılı plastik özeliklerinin oluşturulması gerekmektedir. Taşıyıc1 sistem elemanların plastik mafsal özeliklerinin tanımlanabilmesi için kesitlerin karşılıklı etkileşim diyagramlarının ve moment eğrilik analizleri ile belirlenen hasar sinırlarının belirlenmesi gerekmektedir. Yapılan çalışmada kesitlerin etkileşim diyagramları ve moment eğrilik grafikleri, SAP 2000 V20 programinın "Section Desinger" arayüzü kullanılarak elde edilmiştir.

Sargisız betonun DBYBHY ve TBDY esaslarina göre oluşturulan gerilme - şekil değiştirme diyagramları Sekil 6'da verilmiștir. Grafiklerden görüleceği üzere DBYBHY'de gerilme şekil değiştirme grafiğinin doğrusal davranış göstermeye başladığı şekil değiştirme değeri 0.004 iken, TBDY'de bu değer 0.0035 olarak verilmiştir. 


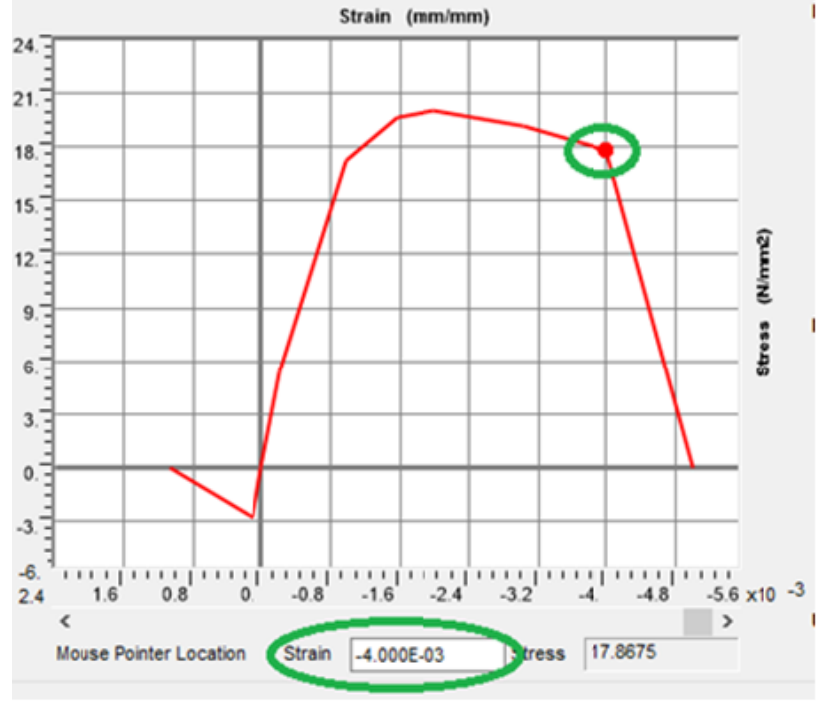

(a)

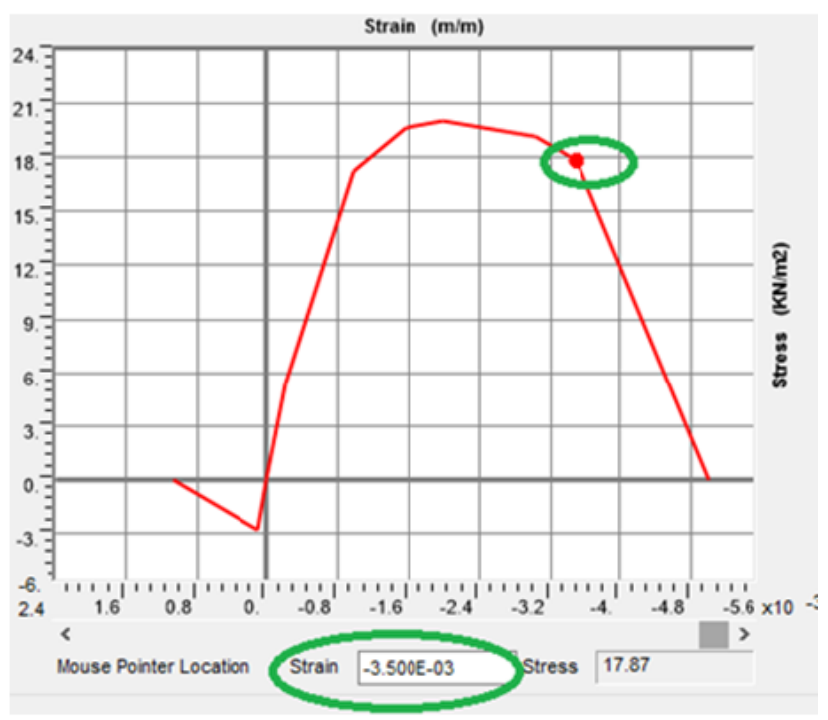

(b)

Şekil 6. Betonun DBYBHY (a) ve TBDY (b) yönetmeliklerine göre oluşturulan gerilme-şekil değiştirme diyagramları

İncelenen binada kullanılan donatının DBYBHY ve TBDY esaslarına göre oluşturulan gerilme şekil değiştirme diyagramları Şekil 7'de verilmiştir. Grafikteki donatıya ait bilgiler,

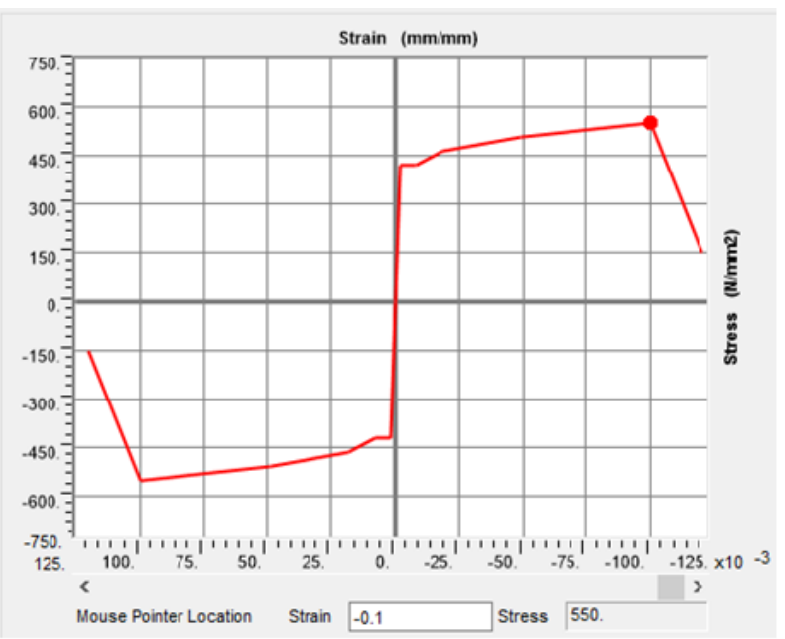

(a)
DBYBHY esaslarına göre olușturulan model için ilgili yönetmeliğin 7B.2. maddesinden, TBDY esaslarına göre oluşturulan model için ise ilgili yönetmelikteki Tablo 5A.1.'den alınmıştır.

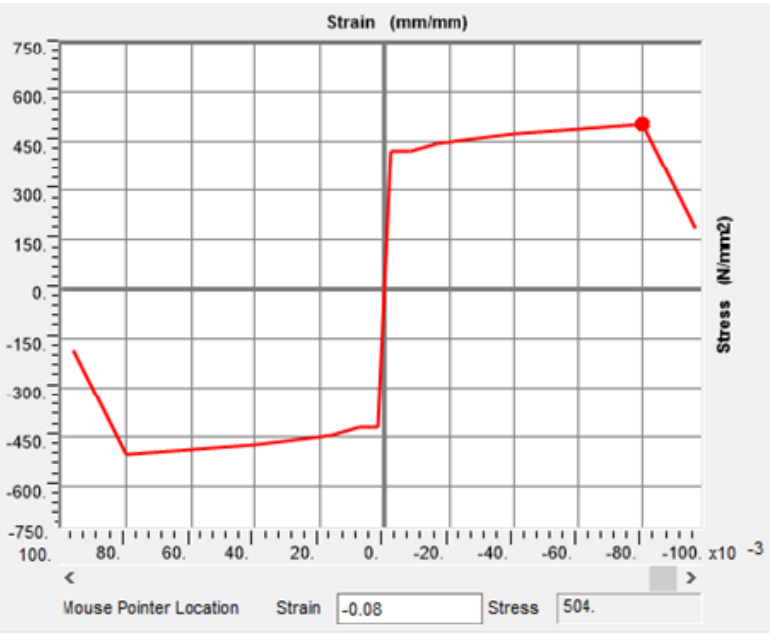

(b)

Şekil 7. Donatının DBYBHY (a) ve TBDY (b) yönetmeliklerine göre oluşturulan gerilme - şekil değiştirme diyagramları

Yapılan moment eğrilik analizleri sonucunda kesitlere ait akma eğrilikleri $\left(\phi_{\mathrm{y}}\right)$, akma momentleri $\left(\mathrm{M}_{\mathrm{y}}\right)$, göçme öncesi eğrilikleri $\left(\phi_{\mathrm{u}}\right)$, göçme öncesi momentleri $\left(\mathrm{M}_{\mathrm{u}}\right)$ elde edilmiştir. Elde edilen moment eğrilik analizi verileri hazırlanan Excel formatında bir dosyaya aktarılmıştır. Söz konusu Excel dosyasında yapılan bazı düzenlemeler ile DBYBHY ve TBDY esaslarına göre kesit plastik dönme sinır değerleri elde edilmiştir. Kolon ve kirişlerin plastik mafsal özelikleri belirlendikten sonra bu özelikler Sap 2000 de tanımlanmıştır. Kesitlerin plastik mafsallar özellikleri için Sap
2000 'in "hinge properites" arayüzünden faydalanılmıştır. Kirişler basit eğilmeye çalıştı̆̆ için M3 plastik mafsal özelliği kullanılmıştır. Kolonlar eksenel kuvvet ve eğilme momentine birlikte maruz kaldıklarından bu elemanlarda PM2-M3 plastik mafsal özelliği kullanılmıştır. Kolon kesitlerinin plastik mafsal özelliklerinin tanımlanması için karşılıklı etki diyagramlarının da oluşturulması gerekmektedir. Bu çalışmada, $0^{0}, 45^{0}$ ve $90^{\circ}$ olmak üzere 3 farklı akma yüzeyi için karşılıklı etki diyagramı tanımlanmıştır. Karşılıklı etki diyagramlarının her biri 9 eksenel yük $(\mathrm{P})$ ve 
eğilme momenti (M2-M3) değeri ile oluşturulmuştur. Bu değerler ilgili kesitin "Section desinger" modelinden alınmıştır. Plastik mafsallar tanımlandıktan sonra bu mafsalların kolon ve kiriş kesitlerinin her iki ucuna atanmıştır.

\subsection{Statik itme analizinin yapılması}

DBYBHY ve TBDY yönetmeliklerinin ikisine göre de statik itme analizi yapılmadan önce statik düşey yüklerin taşıyıcı sisteme artımsal olarak uygulandığ1 doğrusal olmayan statik hesap yapılmas1 gerekmektedir. Bu hesap ile elde edilen iç kuvvetler ve şekil değiştirmeler yatay deprem hesabının başlangıç değerleri olarak göz önüne alınmalıdır. TBDY'e göre statik düşey yükler Denklem 1 ile belirlenmektedir.

$$
\mathrm{G}+\mathrm{nQ}+0.3 \mathrm{E}_{\mathrm{d}}^{(\mathrm{Z})}
$$

Burada; G sabit yükü, Q hareketli yükü, $\mathrm{n}$ ise hareketli yük azaltma katsayısını göstermektedir. Düşey deprem etkisini gösteren $\mathrm{E}_{\mathrm{d}}^{(\mathrm{Z})}$ ise Denklem 2 ile hesaplanmaktadır.

$$
\mathrm{E}_{\mathrm{d}}^{(\mathrm{Z})}=2 / 3 * \mathrm{~S}_{\mathrm{DS}} * \mathrm{G}
$$

Denklem 2'de geçen $\mathrm{S}_{\mathrm{DS}}$ değeri deprem düzeyine bağlı olarak değişmektedir. TBDY'e göre mevcut konut türü binaların hedef performans seviyesi, 50 yılda aşılma olasıllı̆ $1 \% 10$ olan depremler (DD-2 deprem düzeyi) için Kontrolü Hasar (KH)'dır. Çalışma kapsamında incelenen binanın kullanım amacı konut olduğu için hareketli yük azaltma katsayıs1 (n) 0.3, $\mathrm{S}_{\mathrm{DS}}$ değeri ise DD-2 için 1.093 alınmıştır. $S_{D S}$ ve $n$ değerlerinin denklemlerde yerine yazılmasıyla TBDY'e göre yapılacak itme analizinin doğrusal olmayan statik düşey yüklemesinin bağıntısı Denklem 3 ile elde edilmiş olur.

$$
1.2186 \mathrm{G}+0.3 \mathrm{Q}
$$

DBYBHY'e yapılacak itme analizinde kullanılacak olan doğrusal olmayan statik düşey yüklemenin bağıntısı Denklem 4'te verilmiştir.

$G+0.3 Q$

DBYBHY ve TBDY esaslarına göre oluşturulan Sap 2000 modelleri her iki doğrultuda statik itme analizlerine tabi tutulmuştur. Yapılan analiz sonucu elde edilen kapasite eğrileri Şekil 8'de verilmiştir.

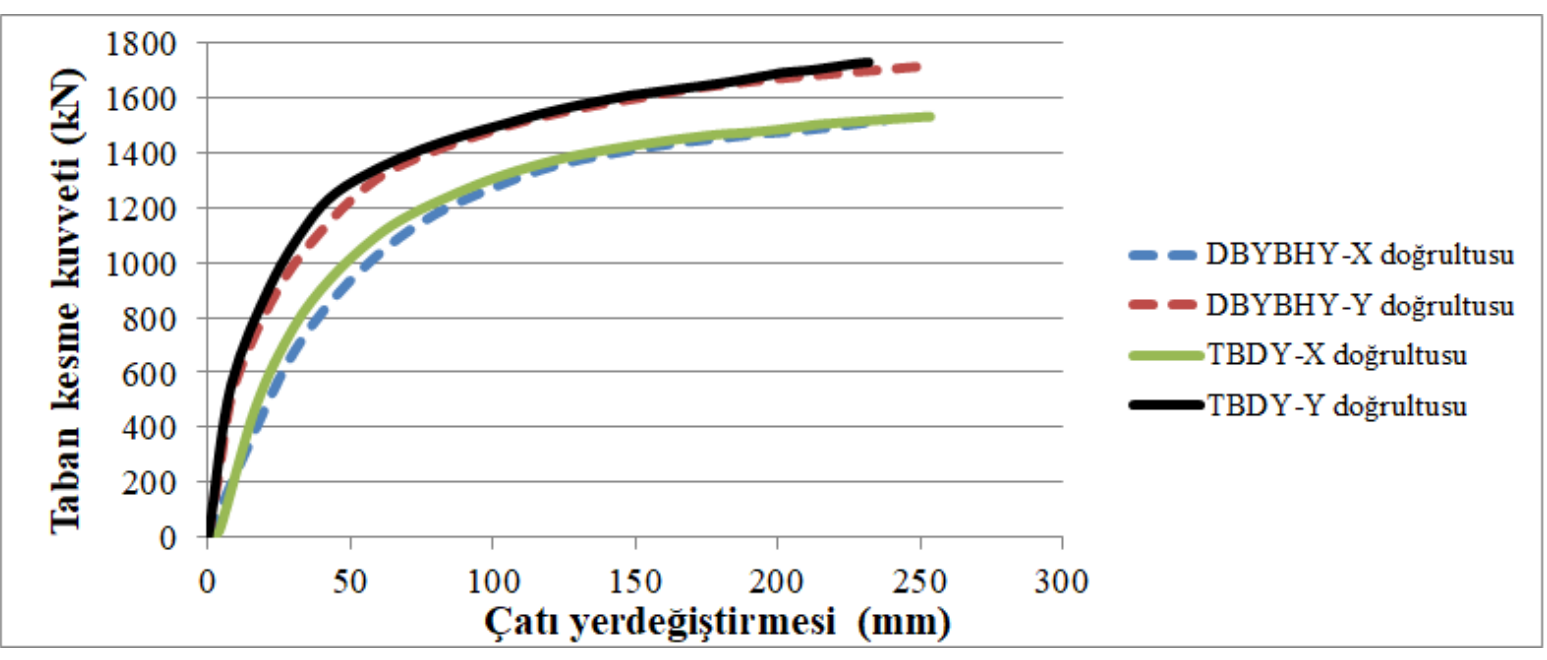

Şekil 8. Kapasite eğrileri

Şekil 8 incelendiğinde, DBYBHY ve TBDY esaslarına göre elde edilen kapasite eğrilerinin bazı noktalarda birbirinden farklı olduğu görülmektedir. $\mathrm{Bu}$ farklılıkların oluşmasına sebep olan temel etmenlerin, yönetmelikler arasındaki plastik mafsal tanımlamalarındaki farklılıklar, malzeme plastik özelliklerindeki farkl1lıklar, kesit etkin rijitlik çarpan farklılıkları ve doğrusal olmayan statik hesap tanımlamada TBDY'nin düşey deprem etkisini dikkate alması, DBYBHY'nin ise bu etkiyi dikkate almaması şeklinde sıralanabilir.
Statik itme yöntemlerinden biri ile deprem performansı belirlenecek bir binanın her iki doğrultu için hedef yerdeğiştirme isteminin belirlenmesi gerekmektedir. Hedef yerdeğiştirme isteminin elde edilmesi için modal kapasite spektrumu ile talep spektrumunun kesiştirmesi gerekmektedir. Modal kapasite spektrumu, itme analizi sonucu elde edilen kapasite eğrisinin eksen dönüştürme işlemi yapılması ile elde edilir. Eksen dönüştürme işleminde amaç; kapasite eğrisi ile talep spektrumunu aynı grafik üzerinde buluşturmaktır. Söz konusu bu işlemler oluşturulan 
bir excel dosyası ile yapılmıştır. $\mathrm{X}$ hesap doğrultusunun DBYBHY'e göre elde edilen hedef yerdeğiştime istemi Şekil 9.a'da, TBDY'e göre elde edilen hedef yerdeğiştime istemi Şekil 9.b'de,

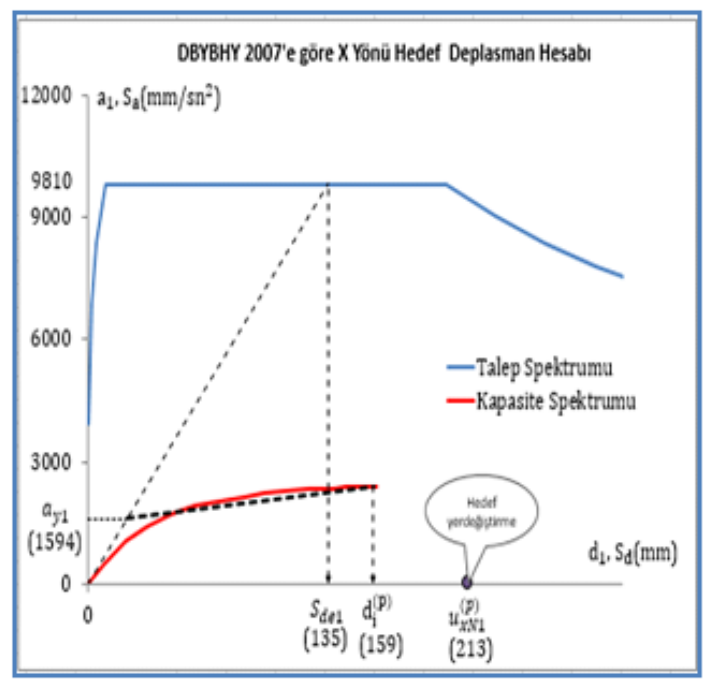

(a)

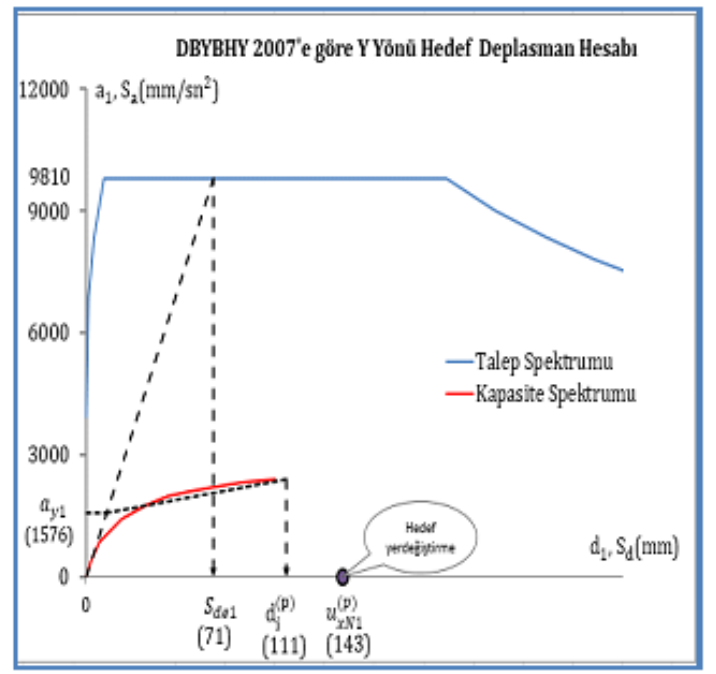

(c)
Y hesap doğrultusunun DBYBHY'e göre elde edilen hedef yerdeğiştime istemi Şekil 9.c'de, TBDY'e göre elde edilen hedef yerdeğiştime istemi Şekil 9.d'de, verilmiştir.

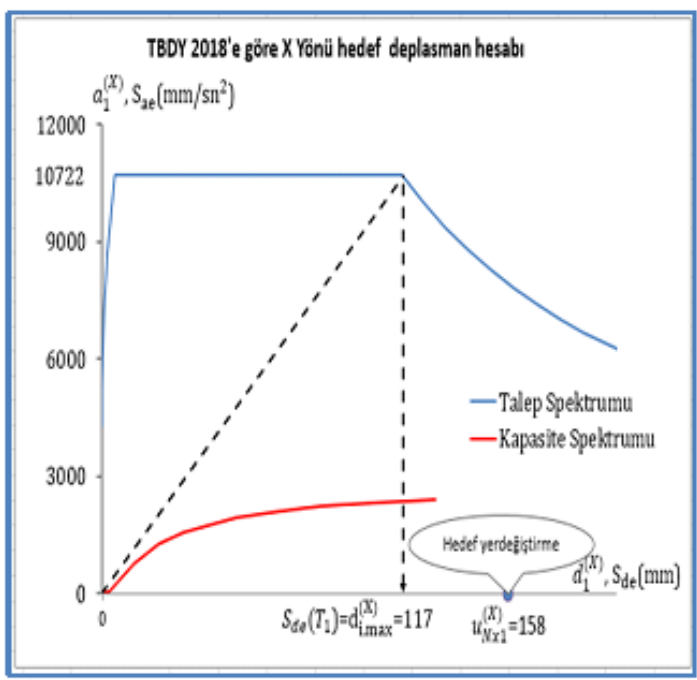

(b)

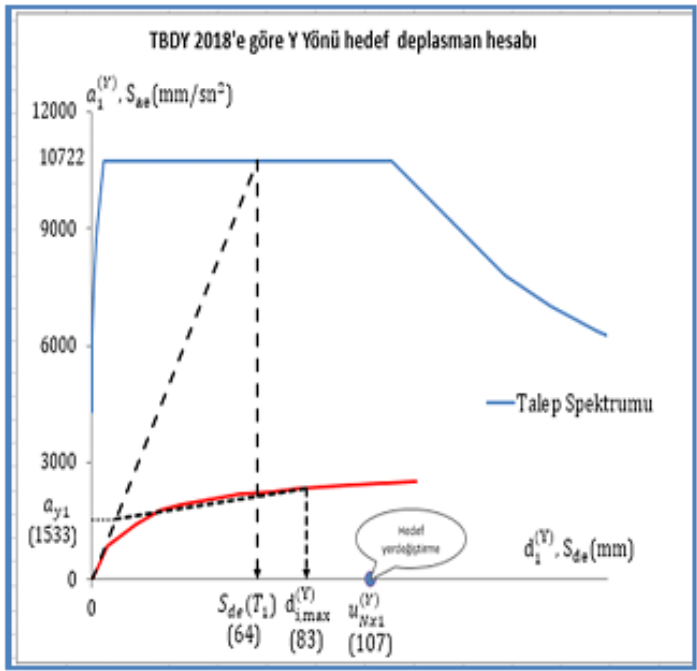

(d)

Şekil 9. Hedef yerdeğiştirme istemlerinin elde edilmesi

Şekil 9'da verilen grafikler ile elde edilen hedef yerdeğişme istemleri, her iki yönetmelik için aynı grafik üzerinde gösterilerek kıyaslanmıştır (Şekil 10). Şekilden de görüldüğü üzere her iki doğrultuda da DBYBHY ile elde edilen hedef yer değiștirme istemleri TBDY'den daha fazla çıkmıştır. Bu durum, binanın DBYBHY modelinin TBDY'ye daha büyük ötelenme değerlerine kadar itileceğini dolayısıyla DBYBHY modelinde taşıyıcı elemanlarda daha fazla şekildeğiştirmeler meydana geleceğini göstermektedir.

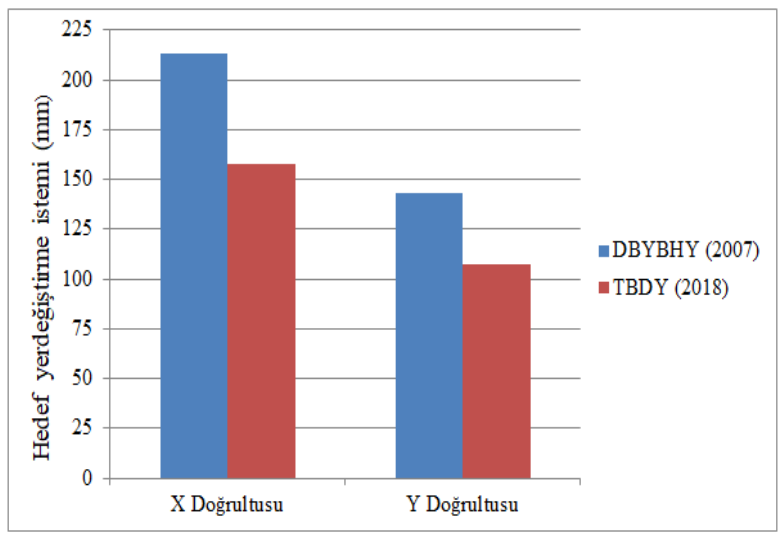

Şekil 10. Hedef yerdeğiştirme istemlerinin k1yaslanmas1 
DBYBHY ve TBDY esaslarına göre oluşturulan Sap 2000 modelleri her iki doğrultuda hedef yerdeğiştirme istemine kadar statik itme analizine tabi tutulmuştur. Böylece 4 farklı statik itme analizi için her bir taşıyıcı elemanda meydana gelen hasarlar belirlenmiştir. $\mathrm{X}$ hesap doğrultusunun DBYBHY'e göre elde edilen hasarları Şekil 11.a,'da, TBDY'e göre elde edilen hasarları Şekil 11.b'de, Y hesap doğrultusunun DBYBHY'e göre

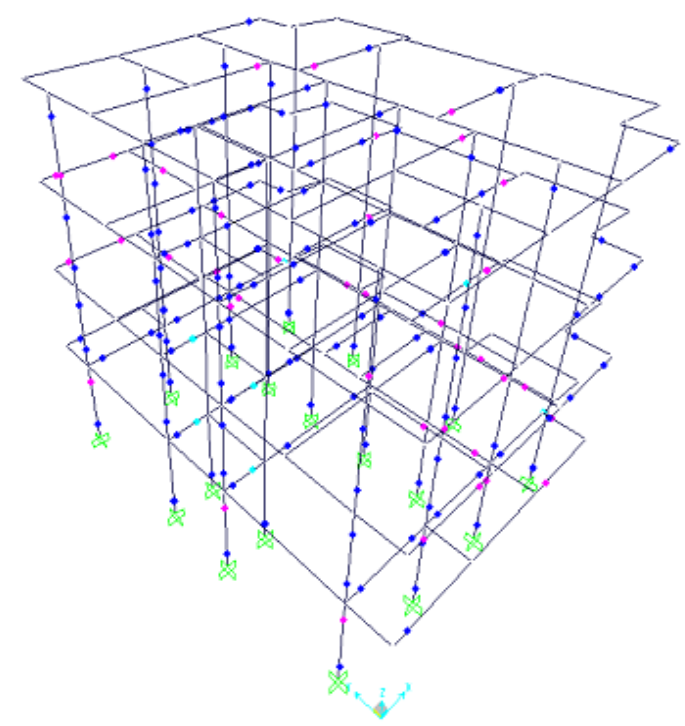

DBYBHY'e göre $\mathrm{x}$ - hesap doğrultusu hasarları

(a)

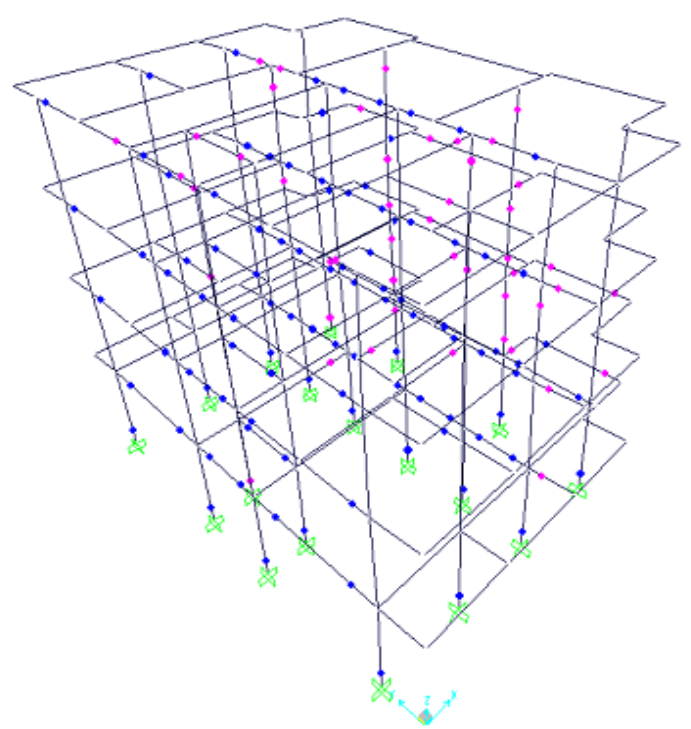

DBYBHY'e göre y-hesap doğrultusu hasarları

(c) elde edilen hasarları Şekil 11.c'de, TBDY'e göre elde edilen hasarları Şekil 11.d'de verilmiştir. Şekil 11.a ve Şekil 11.c'de pembe ile gösterilen plastik mafsallar kesitin Minimum Hasar Bölgesinde kaldığını göstermektedir. Şekil 11'de mavi ile gösterilen plastik mafsallar kesitin Belirgin Hasar Bölgesinde kaldığını, turkuaz ile gösterilen plastik mafsallar ise kesitin İleri Hasar Bölgesinde kaldığını göstermektedir.

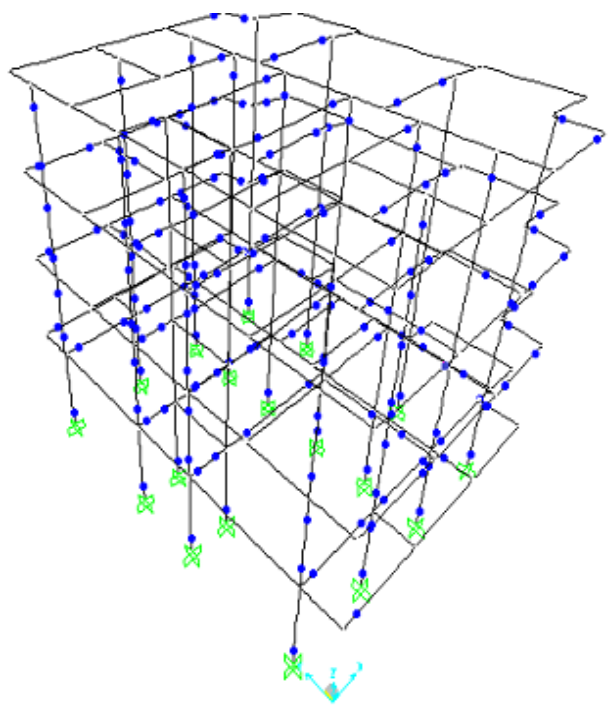

TBDY'e göre $\mathrm{x}$ - hesap doğrultusu hasarları

(b)

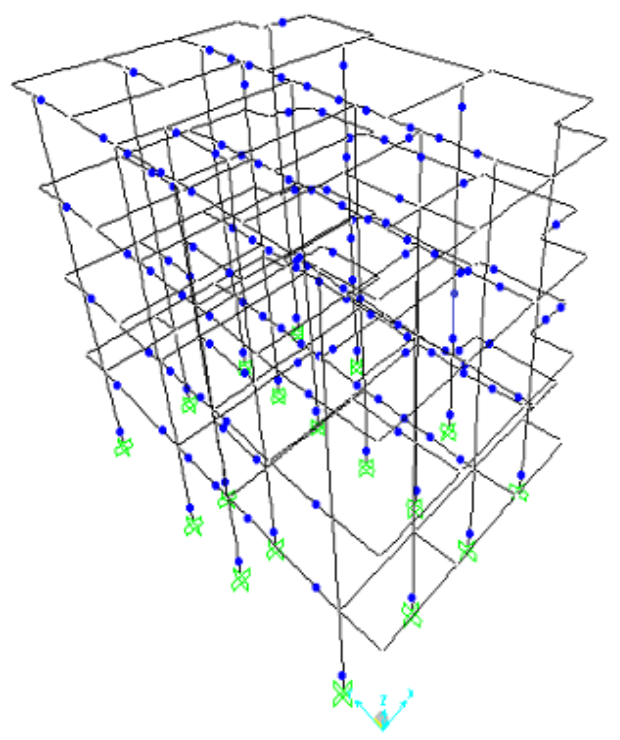

TBDY'e göre y-hesap doğrultusu hasarları

(d)

Şekil 11. Statik itme analizi sonucu taşıyıcı elemanlarda oluşan hasarlar

Kiriş ve kolon kesintilerinin hasarları belirlendikten sonra binanın performans değerlendirmesi yapılmıştır. Binanın performans değerlendirmesi; statik itme analiziyle taşıyıcı elemanlarda meydana gelen hasar ve kesme kuvvetlerinin ilgili yönetmelikteki ilgili koşulla kıyaslanmasıyla yapılmıştır. Bina performans seviyesinin belirlenmesinde kullanılan statik itme analizi verileri Tablo 5 'te verilmiştir. 
Tablo 5.a. DBYBHY' e göre yapılan analiz sonucu elde edilen kolon verileri

\begin{tabular}{|c|c|c|c|c|c|c|c|c|c|c|c|c|c|}
\hline \multirow[t]{2}{*}{$\begin{array}{l}\mathrm{K} \\
\mathrm{a} \\
\mathrm{t}\end{array}$} & \multirow[t]{2}{*}{$\begin{array}{c}\text { Hasar } \\
\text { bölgesi }\end{array}$} & \multicolumn{2}{|c|}{$\begin{array}{c}\text { Hasar bölgesinde } \\
\text { kalan kolon } \\
\text { say1s1 }\end{array}$} & \multicolumn{2}{|c|}{$\begin{array}{l}\text { Kat kesme } \\
\text { kuvvetleri } \\
\qquad(\mathrm{kN})\end{array}$} & \multicolumn{2}{|c|}{$\begin{array}{c}\text { DBYBHY } \\
\text { madde 7.7.3.b'ye } \\
\text { göre kesme } \\
\text { kuvveti }\end{array}$} & \multicolumn{2}{|c|}{$\begin{array}{l}\text { DBYBHY } \\
\text { madde } \\
\text { 7.7.3.b'ye göre } \\
\text { oran }(\%)\end{array}$} & \multicolumn{2}{|c|}{$\begin{array}{c}\text { DBYBHY } \\
\text { madde 7.7.3.c'ye } \\
\text { göre kesme } \\
\text { kuvveti }\end{array}$} & \multicolumn{2}{|c|}{$\begin{array}{c}\text { DBYBHY } \\
\text { madde } \\
\text { 7.7.3.c'ye } \\
\text { göre oran } \\
(\%)\end{array}$} \\
\hline & & $X$ & Y & $X$ & Y & $X$ & Y & $X$ & Y & $X$ & $\mathrm{Y}$ & $X$ & $\mathrm{Y}$ \\
\hline \multirow{3}{*}{1} & MHB & 0 & 2 & \multirow{3}{*}{1491} & \multirow{3}{*}{1587} & \multirow{3}{*}{0} & \multirow{3}{*}{0} & \multirow{3}{*}{0} & \multirow{3}{*}{0} & \multirow{3}{*}{153} & \multirow{3}{*}{0} & \multirow{3}{*}{10} & \multirow{3}{*}{0} \\
\hline & BHB & 18 & 16 & & & & & & & & & & \\
\hline & $\begin{array}{l}\text { İHB } \\
\text { GB }\end{array}$ & $\begin{array}{l}0 \\
0\end{array}$ & $\begin{array}{l}0 \\
0\end{array}$ & & & & & & & & & & \\
\hline \multirow{4}{*}{2} & MHB & 10 & 18 & \multirow{4}{*}{1346} & \multirow{4}{*}{1396} & \multirow{4}{*}{0} & \multirow{4}{*}{0} & \multirow{4}{*}{0} & \multirow{4}{*}{0} & \multirow{4}{*}{372} & \multirow{4}{*}{0} & & \\
\hline & $\mathrm{BHB}$ & 8 & 0 & & & & & & & & & 28 & 0 \\
\hline & İHB & 0 & 0 & & & & & & & & & 20 & 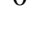 \\
\hline & GB & 0 & 0 & & & & & & & & & & \\
\hline & MHB & 12 & 18 & & & & & & & & & & \\
\hline & $\mathrm{BHB}$ & 6 & 0 & 1008 & 1010 & 0 & 0 & 0 & 0 & 368 & 0 & 37 & 0 \\
\hline 3 & İHB & 0 & 0 & 1000 & 1010 & 0 & 0 & 0 & 0 & & 0 & & 0 \\
\hline & GB & 0 & 0 & & & & & & & & & & \\
\hline & MHB & 8 & 18 & & & & & & & & & & \\
\hline 4 & ВHB & 10 & 0 & 1037 & 572 & 0 & 0 & 0 & 0 & 232 & 0 & 22 & 0 \\
\hline 7 & İHB & 0 & 0 & 1001 & 312 & 0 & 0 & 0 & 0 & 252 & 0 & 22 & 0 \\
\hline & GB & 0 & 0 & & & & & & & & & & \\
\hline
\end{tabular}

Tablo 5.b. TBDY'e göre yapılan analiz sonucu elde edilen kolon verileri

\begin{tabular}{|c|c|c|c|c|c|c|c|c|c|c|c|c|c|}
\hline \multirow[t]{2}{*}{$\begin{array}{l}\mathrm{K} \\
\mathrm{a} \\
\mathrm{t}\end{array}$} & \multirow[t]{2}{*}{$\begin{array}{c}\text { Hasar } \\
\text { bölgesi }\end{array}$} & \multicolumn{2}{|c|}{$\begin{array}{c}\text { Hasar } \\
\text { bölgesinde } \\
\text { kalan kolon } \\
\text { sayısı } \\
\text { Doğrultu }\end{array}$} & \multicolumn{2}{|c|}{$\begin{array}{l}\text { Kat kesme } \\
\text { kuvvetleri } \\
\quad(\mathrm{kN})\end{array}$} & \multicolumn{2}{|c|}{$\begin{array}{c}\text { TBDY } \\
\text { madde } \\
\text { 15.8.4.b'ye göre } \\
\text { kesme kuvveti } \\
\\
\text { Doğrultu }\end{array}$} & \multicolumn{2}{|c|}{$\begin{array}{c}\text { TBDY } \\
\text { madde } \\
\text { 15.8.4.b'ye } \\
\text { göre oran (\%) } \\
\text { Doğrultu }\end{array}$} & \multicolumn{2}{|c|}{$\begin{array}{c}\text { TBDY } \\
\text { madde } \\
\text { 15.8.4.c'ye göre } \\
\text { kesme kuvveti } \\
\text { Doğrultu }\end{array}$} & \multicolumn{2}{|c|}{$\begin{array}{c}\text { TBDY } \\
\text { madde } \\
\text { 15.8.4.c'ye } \\
\text { göre } \\
\text { oran (\%) } \\
\text { Doğrultu }\end{array}$} \\
\hline & & $X$ & $\mathrm{Y}$ & $X$ & Y & $X$ & $\mathrm{Y}$ & $X$ & $\mathrm{Y}$ & $X$ & Y & $X$ & Y \\
\hline \multirow{3}{*}{1} & SHB & 0 & 0 & \multirow{3}{*}{1445} & \multirow{3}{*}{1517} & \multirow{3}{*}{0} & \multirow{3}{*}{0} & \multirow{3}{*}{0} & \multirow{3}{*}{0} & \multirow{3}{*}{320} & \multirow{3}{*}{0} & \multirow{3}{*}{22} & \multirow{3}{*}{0} \\
\hline & $\begin{array}{l}\text { BHB } \\
\dot{\text { İHB }}\end{array}$ & $\begin{array}{c}18 \\
0\end{array}$ & $\begin{array}{c}18 \\
0\end{array}$ & & & & & & & & & & \\
\hline & GB & 0 & 0 & & & & & & & & & & \\
\hline \multirow{4}{*}{2} & SHB & 10 & 16 & \multirow{4}{*}{1312} & \multirow{4}{*}{1347} & \multirow{4}{*}{0} & \multirow{4}{*}{0} & \multirow{4}{*}{0} & \multirow{4}{*}{0} & \multirow{4}{*}{358} & \multirow{4}{*}{78} & \multirow{4}{*}{27} & \multirow{4}{*}{6} \\
\hline & BHB & 8 & 2 & & & & & & & & & & \\
\hline & İHB & 0 & 0 & & & & & & & & & & \\
\hline & GB & 0 & 0 & & & & & & & & & & \\
\hline \multirow{4}{*}{3} & SHB & 12 & 17 & \multirow{4}{*}{992} & \multirow{4}{*}{983} & \multirow{4}{*}{0} & & & & & & & \\
\hline & BHB & 6 & 1 & & & & 0 & 0 & 0 & 363 & 0 & 37 & 0 \\
\hline & İHB & 0 & 0 & & & & 0 & 0 & 0 & 363 & 0 & 31 & 0 \\
\hline & GB & 0 & 0 & & & & & & & & & & \\
\hline & SHB & 6 & 14 & & & & & & & & & & \\
\hline 4 & BHB & 12 & 4 & 1027 & & 0 & 0 & 0 & 0 & 341 & 0 & 32 & 0 \\
\hline 4 & İHB & 0 & 0 & 1022 & 576 & 0 & 0 & 0 & 0 & 341 & 0 & 33 & 0 \\
\hline & GB & 0 & 0 & & & & & & & & & & \\
\hline
\end{tabular}


Tablo 5.c. Kiriş hasar verileri

\begin{tabular}{|c|c|c|c|c|c|c|c|c|c|c|}
\hline \multicolumn{6}{|c|}{ DBYBHY } & \multicolumn{5}{|c|}{ TBDY } \\
\hline \multirow[t]{2}{*}{ Kat } & \multirow[t]{2}{*}{$\begin{array}{c}\text { Hasar } \\
\text { bölgesi }\end{array}$} & \multicolumn{2}{|c|}{$\begin{array}{l}\text { Hasar bölgesinde } \\
\text { kalan kiriş sayısı } \\
\text { Doğrultu }\end{array}$} & \multicolumn{2}{|c|}{$\begin{array}{l}\text { Hasar bölgesinde } \\
\text { kalan kiriş yüzdesi } \\
\text { Doğrultu }\end{array}$} & \multirow[t]{2}{*}{$\begin{array}{l}\text { Hasar } \\
\text { bölgesi }\end{array}$} & \multicolumn{2}{|c|}{$\begin{array}{l}\text { Hasar bölgesinde } \\
\text { kalan kiriş sayıs1 } \\
\text { Doğrultu }\end{array}$} & \multicolumn{2}{|c|}{$\begin{array}{l}\text { Hasar bölgesinde } \\
\text { kalan kiriş yüzdes } \\
\text { Doğrultu }\end{array}$} \\
\hline & & $\mathrm{X}$ & $\mathrm{Y}$ & X & $\mathrm{Y}$ & & $X$ & $\mathrm{Y}$ & $\mathrm{X}$ & $\mathrm{Y}$ \\
\hline \multirow{4}{*}{1} & MHB & 8 & 8 & 44 & 36 & SHB & 8 & 8 & 44 & 36 \\
\hline & BHB & 10 & 14 & 56 & 64 & BHB & 14 & 14 & 78 & 64 \\
\hline & İHB & 4 & 0 & 22 & 0 & $\dot{\mathrm{I}} \mathrm{HB}$ & 0 & 0 & 0 & 0 \\
\hline & GB & 0 & 0 & 0 & 0 & GB & 0 & 0 & 0 & 0 \\
\hline \multirow{4}{*}{2} & MHB & 6 & 10 & 33 & 45 & SHB & 0 & 7 & 0 & 32 \\
\hline & BHB & 9 & 12 & 50 & 55 & BHB & 18 & 15 & 100 & 68 \\
\hline & İHB & 3 & 0 & 17 & 0 & İHB & 0 & 0 & 0 & 0 \\
\hline & GB & 0 & 0 & 0 & 0 & GB & 0 & 0 & 0 & 0 \\
\hline \multirow{4}{*}{3} & MHB & 6 & 11 & 33 & 50 & SHB & 0 & 8 & 0 & 36 \\
\hline & BHB & 12 & 11 & 67 & 50 & BHB & 18 & 14 & 100 & 64 \\
\hline & İHB & 0 & 0 & 0 & 0 & İHB & 0 & 0 & 0 & 0 \\
\hline & GB & 0 & 0 & 0 & 0 & GB & 0 & 0 & 0 & 0 \\
\hline \multirow{4}{*}{4} & MHB & 10 & 13 & 56 & 59 & SHB & 8 & 11 & 44 & 50 \\
\hline & BHB & 8 & 9 & 44 & 41 & BHB & 10 & 11 & 56 & 50 \\
\hline & İHB & 0 & 0 & 0 & 0 & İHB & 0 & 0 & 0 & 0 \\
\hline & GB & 0 & 0 & 0 & 0 & GB & 0 & 0 & 0 & 0 \\
\hline
\end{tabular}

Tablo 5'de yer alan veriler kullanarak her iki deprem yönetmeliği için her iki doğrultuda bina performans seviyesi belirlenmiş elde edilen performans sonuçları Tablo 6' da verilmiştir. Tablo 6'da parantez içerisinde italik olarak yazılan değerler TBDY'e göre elde edilen değerlerdir. Bu tez çalışmasının amacı, DBYBHY ve TBDY deprem yönetmeliklerinin deprem performas1 açısından kıyaslanması olduğundan, kolon hasarları dikkate alınmadan yalnızca kiriş hasarları ile kıyaslama, kiriş hasarı dikkate alınmadan yalnızca kolon hasarları ile kıyaslama ve kolon ile kiriş hasarlarının ikisi de dikkate alınarak kıyaslama olmak üzere 3 farklı şekilde kıyaslama yapılmıştır. Böylece yönetmelikler daha detaylı bir şekilde karşılaştırılmıştır.

Tablo 6. Bina performans değerlendirme sonuçları

\begin{tabular}{|c|c|c|c|c|c|c|}
\hline \multicolumn{5}{|c|}{ Yalnızca kirişlerde meydana gelen hasarlara göre değerlendirme } & \multicolumn{2}{|c|}{ Bina Performans Seviyesi } \\
\hline Kat & $\mathrm{x}$ - doğrultusu & y- doğrultusu & x- doğrultusu & y- doğrultusu & x- doğrultusu & $y-$ doğrultusu \\
\hline 1 & $\begin{array}{l}\text { CG } \\
(K H)\end{array}$ & $\begin{array}{l}\text { CG } \\
(K H)\end{array}$ & \multirow{4}{*}{$\begin{array}{l}\text { CG } \\
(K H)\end{array}$} & \multirow{4}{*}{$\begin{array}{l}\text { CG } \\
(K H)\end{array}$} & \multirow{10}{*}{$\begin{array}{l}\text { GD } \\
(G D)\end{array}$} & \multirow{10}{*}{$\begin{array}{l}\text { CG } \\
(K H)\end{array}$} \\
\hline 2 & $\mathrm{CG}$ & $\mathrm{CG}$ & & & & \\
\hline 3 & $\begin{array}{c}\mathrm{CG} \\
(\mathrm{KH})\end{array}$ & $\begin{array}{c}\mathrm{CG} \\
(K H))\end{array}$ & & & & \\
\hline 4 & $\begin{array}{c}\mathrm{CG} \\
(\mathrm{KH})\end{array}$ & $\begin{array}{l}\mathrm{CG} \\
(\mathrm{KH})\end{array}$ & & & & \\
\hline & n1zca kolonlard & meydana geler & hasarlara göre & eğerlendirme & & \\
\hline Kat & $\mathrm{x}$ - doğrultusu & $\mathrm{y}$ - doğrultusu & x- doğrultusu & y- doğrultusu & & \\
\hline 1 & $\begin{array}{c}\text { CG } \\
(K H)\end{array}$ & $\begin{array}{c}\mathrm{CG} \\
(\mathrm{KH})\end{array}$ & \multirow{4}{*}{$\begin{array}{l}\text { GD } \\
(G D)\end{array}$} & \multirow{4}{*}{$\begin{array}{l}\text { CG } \\
(K H)\end{array}$} & & \\
\hline 2 & $\begin{array}{c}\mathrm{CG} \\
(\mathrm{KH})\end{array}$ & $\begin{array}{l}\mathrm{HK} \\
(K H)\end{array}$ & & & & \\
\hline 3 & $\begin{array}{l}\text { GD } \\
(G D)\end{array}$ & $\begin{array}{l}\mathrm{HK} \\
(K H)\end{array}$ & & & & \\
\hline 4 & $\begin{array}{c}\text { CG } \\
(G D)\end{array}$ & $\begin{array}{l}\mathrm{HK} \\
(K H)\end{array}$ & & & & \\
\hline
\end{tabular}

\section{Analiz sonuçları ve bulgular}

Mevcut konut türü bir binanın 50 yılda aşılma olasıllı̆̆ $1 \% 10$ olan depremler için DBYBHY'e göre Can Güvenlği (CG), TBDY'e göre ise Kontrollu
Hasar (KH) hedef performans seviyesini sağlamaları gerekmektedir. Bu bilgi doğrultusunda yapılan performans değerlendirmeleri ile elde edilen sonuçlar aşağıda maddeler halinde sıralanmıştır. 
TBDY'e göre kolonların etkin kesit rijitlik çarpanları eksenel yük seviysinden bağımsız olarak 0.7 alınmakta, DBYBHY'e göre ise eksenel yük seviyesine bağlı olarak belirlenmektedir. DBYBHY esaslarına göre incelenen binada, kolonların etkin kesit rijitlik çarpanları 0.4-0.5 seviyelerinde çıkmıştır. Etkin kesit rijitlik çarpanlarında oluşan bu farklılığın sebebi incelenen binanın düşük katlı olmasından dolayıdır. Düşük katlı binalarda düşey elemanlarda oluşan eksenel yük seviyesi düşük seviyelerde olduğundan ve DBYBHY'e göre eksenler yük seviyesi ile etkin kesit rijitlik çarpanları da de ters orantılı olduğundan etkin kesit rijitlikleri düşük seviyede çıkmıştır.

> DBYBHY'e esaslarına göre oluşturulan modelde binanın periyodu $\mathrm{x}$ - doğrultusu için $0.74 \mathrm{sn}, \mathrm{y}$ - doğrultusu için 0.53 sn olarak elde edilmişken, TBDY'e esaslarına göre oluşturulan modelde bu değerler sırasıyla 0.66 sn ve 0.49 sn olarak elde edilmiştir. Periyodların yönetmeliklere göre farklı çıkmasının sebebi etkin kesit rijitlik çarpanlarındaki farklilıktan kaynaklanmaktadır.

$>$ Binanın $\mathrm{x}$ - ve $\mathrm{y}$ - doğrultularının her ikisinde de TBDY'e göre elde edilen hedef yerdeğiştirme istemleri DBYBHY'e göre yaklaşık \% 25 daha az çıkmıştır. Bu durumun temel sebebi yönetmelik esaslarına göre düzenlenen modellerdeki periyot farklı1ıkları ve elastik spektrum eğrilerinin farklı olmasindandir.

$>$ Yalnızca kiriş hasarlarına göre performans değerlendirilmesi yapılırsa (kolon hasarları dikkate alınmazsa), DBYBHY'e göre yapılan çözümlerde tüm katların her iki doğrultusu da CG performans seviyesinde, TBDY'e göre yapılan çözümlerde ise tüm katların her iki doğrultusu $\mathrm{KH}$ hedef performans seviyesindedir. Dolayısı ile yalnızca kiriş hasarlarına göre performans değerlendirilmesi yapılırsa binanın her iki doğrultusu her iki yönetmeliğe göre de hedef performans seviyesini sağlamaktadır.

$>$ Yalnızca kolon hasarlarına göre performans değerlendirilmesi yapılırsa (kiriş hasarları dikkate alınmazsa), DBYBHY'e göre yapılan çözümlerde $\mathrm{x}$ - doğrultusu GD performans seviyesinde, $y$ - doğrultusu ise CG performans seviyesindedir. TBDY'e göre yapılan çözümlerde ise $\mathrm{x}$ - doğrultusu GD performans seviyesinde, $\mathrm{y}$ - doğrultusu ise $\mathrm{KH}$ performans seviyesindedir. Dolayısı ile yalnızca kolon hasarları dikkate alındığında her iki yönetmeliğe göre de bina $\mathrm{x}$ - doğrultusunda hedef performans seviyesini sağlamamakta, $y$ doğrultusunda ise hedef performans seviyesini sağlamaktadır.

$>$ Tüm elemanların hasarları dikkate alındığında, DBYBHY'e göre yapılan çözümlerde $\mathrm{x}$ - doğrultusu GD performans seviyesinde, $y$ - doğrultusu ise CG performans seviyesindedir. TBDY'e göre yapılan çözümlerde ise $\mathrm{x}$ - doğrultusu GD performans seviyesinde, $\mathrm{y}$ - doğrultusu ise $\mathrm{KH}$ performans seviyesindedir. Dolayısı ile tüm elemanların hasarları dikkate alındığında her iki yönetmeliğe göre de bina $\mathrm{x}$ - doğrultusunda hedef performans seviyesini sağlamamakta, $y$ doğrultusunda ise hedef performans seviyesini sağlamaktadır.

$>$ DBYBHY'e göre bina performans seviyesinin Göçme durumu olmasının sebebi, 3. Katta alt ve üst kesitlerinin ikisinde birden Minimum Hasar Sınırı aşılmış olan kolonlar tarafindan taşınan kesme kuvvetlerinin, 3. katta ki tüm kolonlar tarafından taşınan kesme kuvvetine oranının 30 'u aşmasından dolayıdır. TBDY'e göre bina performans seviyesinin Göçme durumu olmasinın sebebi ise hem 3 . hem de 4 . katlarda, alt ve üst kesitlerinin ikisinde birden Belirgin Hasar Sınırı aşılmış olan düşey elemanlar tarafından taşınan kesme kuvvetlerinin, o kattaki tüm düşey elemanlar tarafından taşınan kesme kuvvetine oranının \%30'u aşmasından dolayıdır.

\section{Tartışma ve sonuçlar}

$\mathrm{Bu}$ çalışmada, mevcut 4 katlı konut türü bir binanın DBYBHY ve TBDY deprem yönetmeliklerine göre deprem güvenliği incelenmiş, iki yönetmeliğe göre elde edilen sonuçlar birbiri ile karşılaştırılmıştır. Seçilen mevcut binanın kat sayısının düşük seçilmesinin sebebi, düşey elemanlarda düşük eksenel yüklerin oluşması, buna bağlı olarak da DBYBHY modelinde kullanılacak olan etkin kesit rijitliklerininde düşük seviyede çıkmasının istenmesindendir. Yönetmelikler arasında oluşan etkin kesit rijitlik farklılıklarının da hedef performasn seviyesini oldukça etkilediği görülmüştür. Binanın x- ve y- doğrultularının her ikisinde de TBDY'e göre elde edilen hedef yerdeğiştirme istemleri DBYBHY'e göre yaklaşık $\% 25$ daha az çıkmıştır. İncelenen bina her iki yönetmeliğe göre de $\mathrm{x}$ - doğrultusunda hedef performans seviyesini sağlayamamış, $y$ doğrultusunda hedef performans seviyesini sağlayabilmiştir. Dolaysıyla her iki yönetmeliğe göre de bina kullanımı can güvenliği bakımından sakıncalıdır. 
$\mathrm{Bu}$ çalışmada; ABYYHY esaslarına göre tasarlanmış ve 2004 yılında inşa edilmiş, donatı sinifi S420, beton sinifi C20 ve yeterli enine donatıya sahip, taşıyıcı sistemi yalnızca çerçevelerden oluşan mevcut 4 katlı konut türü betonarme bir binanın DBYBHY ve TBDY deprem yönetmeliklerine göre deprem performans sonuçları kıyaslanmıştır. Yapılan bu çalışma DBYBHY ve TBDY deprem yönetmeliklerini deprem güvenliği açısından kıyaslamak ve yönetmeliklerdeki farklılıkları ortaya koymak açısından kapsamlı bir çalışma olmakla beraber yapılacak yeni çalışmalara katkı sunacağ 1 düşünülmektedir. İlerleyen çalışmalarda, boyuna donatıları nervürsüz (düz) donatı çeliği ile düzenlenmiş, beton sınıfi daha düşük, yeterli enine donatıya sahip olmayan, kat adetinin daha fazla olduğu, taşıyıcı sisteminde betonarme perdelerin de olduğu ve kullanım amacı farklı olan mevcut bina türleri için de benzer çalışmaların yapılması, iki yönetmeliğin mevcut binaların deprem güvenliği açısından kıyaslanması için faydalı olacağ1 düşünülmektedir.

\section{Kaynaklar}

ABYYHY, 1998. Afet Bölgelerinde Yapılacak Yapılar Hakkinda Yönetmelik. Bayındırlık ve İskan Bakanlı̆̆ı, Ankara.

Aksoylu, C. Mobark, A., Arslan, M.H. and Erkan, İ.H. (2020). A comparative study on ASCE 7-16, TBEC-2018 and TEC-2007 for reinforced concrete buildings. Revista de la Construcción, $19(2)$, 282-305.

https://doi.org/10.7764/rdlc.19.2.282

Aksoylu, C. ve Arslan, M. (2021). 2007 ve 2019 deprem yönetmeliklerinde betonarme binalar için yer alan farklı deprem kuvveti hesaplama yöntemlerinin karşılaştırılmalı olarak irdelenmesi. International Journal of Engineering Research and Development, 13(2). https://doi.org/10.29137/umagd.844186

Asığçel, Z. (2019). Betonarme binalarda deprem etkisinin DBYBHY 2007 ve TBDY 2018 deprem yönetmeliklerine göre karşılaştırılması. Yüksek Lisans Tezi, Dicle Üniversitesi Fen Bilimleri Enstitüsü, Diyarbakır.

Başaran, V. (2018). Türkiye Bina Deprem Yönetmeliğine (TBDY2019) göre Afyonkarahisar İçin Deprem yüklerinin değerlendirilmesi. Afyon Kocatepe Üniversitesi Fen ve Mühendislik Bilimleri Dergisi, 18(3), 1028-1035. https://doi.org/10.5578/fmbd.67739

DBYBHY, 2007. Deprem Bölgelerinde Yapılacak Binalar Hakkındaki Yönetmelik. Bayındırlık ve İskan Bakanlığı, Ankara.
Demir, A. ve Kayhan A.H. (2017). Deprem Yönetmeliği 2007 ve Türkiye Bina Deprem Yönetmeliği ile uyumlu zaman tanım alanında analiz sonuçlarının karşılaştııılması. 4. Uluslararası Deprem Mühendisliği ve Sismoloji Konferansı, Eskişehir.

Dilmaç, H., Ulutaş, H., Tekeli, H. and Demir, F. (2018). An evaluation on seismic performance of existing reinforced concrete buildings in Turkey. Mehmet Akif Ersoy Üniversitesi Fen Bilimleri Enstitüsü Dergisi, 9(Ek Say1 1): 224-237. https://doi.org/10.29048/makufebed.443126

Dilmaç, H. and Demir, F. (2019). Earthquake vulnerability assessment of rc structures with variable infill wall properties. Avrupa Bilim ve Teknoloji Dergisi, (17), 176-189. https://doi.org/10.31590/ejosat.597194

Engin, S. (2019). Betonarme bir binanın Deprem Bölgelerinde Yapılacak Binalar Hakkında Yönetmelik (DBYBHY-2007) ve Türk Bina Deprem Yönetmeliği (TBDY-2019) koşullarına göre değerlendirilmesi. VI. International Earthquake Symposium (IESKO) (ss.663-668). Kocaeli.

Gündoğay, A., Ulutaş, H. ve Tekeli, H. (2019). Mevcut atölye binalarının deprem güvenliğinin incelenmesi. DÜMF Mühendislik Dergisi, 10(2), 755-768. https://doi.org/10.24012/dumf.432136

Işık, E. (2013). Bitlis ili'nin depremselliği. Erciyes Üniversitesi Fen Bilimleri Enstitüsü Dergisi, 29(3), 267-273.

Işık, E., Büyüksaraç, A., Ekinci, Y.L., Aydın, M.C. and Harirchian, E. (2020). The effect of site-specific design spectrum on earthquake-building parameters: A case study from the Marmara region (NW Turkey). Applied Sciences, 10(20), 7247. https://doi.org/10.3390/app10207247

Işık, E., Ekinci, Y., Sayıl, N., Büyüksaraç, A. and Aydın, M.C. (2021). Time-dependent model for earthquake occurrence and effects of design spectra on structural performance: A case study from the North Anatolian Fault Zone, Turkey. Turkish Journal of Earth Sciences, 30(2), 215234. https://doi.org/10.3906/yer-2004-20

İbiş, T. ve Ulutaş, H. (2021). Yeni yapılacak betonarme bir binanın TBDY 2018'e göre deprem performansının belirlenmesi. Bitlis Eren Üniversitesi Fen Bilimleri Dergisi. 10(3).

Kadaş, K., Soysal, B.F., Akansel, V.H., Mazılıgüney, L. and Yakut, A. (2019). Comparison of 2007 and 2019 seismic hazard maps based on spectrum intensities and corresponding engineering demands - a case study with RC school buildings in Istanbul. 5th International Conference on 
Earthquake Engineering and Seismology, Ankara.

Karaca, H., Oral, M. ve Erbil, M. (2019). Konut tasarımı bağlamında 2007 ve 2018 deprem yönetmeliklerinin karşılaştırılması, Niğde örneği. 21. Ulusal Mekanik Kongresi (ss. 296302). Niğde.

Karaca, H. (2020). Örneklerle TBDY 2019 zemin parametrelerinin kullanılan yapısal malzeme miktarına ve çatı katı yanal ötelenmesine etkisi. Journal of Polytechnic. https://doi.org/10.2339/politeknik.680595.

Karaca, H., Oral, M. ve Erbil, M. (2020). Yapisal tasarım bağlamında 2007 ve 2018 deprem yönetmeliklerinin karşılaştırılması, Niğde örneği. Ömer Halisdemir Üniversitesi Mühendislik Bilimleri Dergisi, 9(2), 898-903. https://doi.org/10.28948/ngumuh.667365

Karasin, İ.B., Işık, E., Demirci, A. ve Aydın, M. (2020). Coğrafi konuma özel tasarım spektrumlarının betonarme yap1 performansına etkisi. Dicle Üniversitesi Mühendislik Fakültesi Mühendislik Dergisi, 11(3), 1319-1330. https://doi.org/10.24012/dumf.682377

Keskin, E. ve Bozdoğan, K.B. (2018). 2007 ve 2018 deprem yönetmeliklerinin Kırklareli ili özelinde değerlendirilmesi. Kırklareli Üniversitesi Mühendislik ve Fen Bilimleri Dergisi, 4(1), 7490.

Kılıç, G. (2019). Betonarme yapıda perde yeri seçiminin yapısal davranışa etkisinin TBDY 2018 ve DBYBHY 2007 yönetmeliklerine göre karşılaştırılması. Yüksek Lisans Tezi, Sakarya Üniversitesi Fen Bilimleri Enstitüsü, Sakarya.

Koçer, M., Nakipoğlu, A., Öztürk, B., Al-Hagri M.G. ve Arslan M.H. (2018). Deprem kuvvetine esas spektral ivme değerlerinin TBDY 2018 ve TDY 2007'ye göre karşılaştırılması. Selçuk Teknik Dergisi, 17(2), 43-58.

SAP2000. Integrated finite element analysis and design of structures, Computers and Structures Inc., Berkeley, California, USA.

Soycan, C. (2019). Depremde betonarme bina performansının Türk deprem yönetmelikleri 2007 ve 2018'e göre değerlendirilmesi. Yüksek
Lisans Tezi, Yıldız Teknik Üniversitesi Fen Bilimleri Enstitüsü, İstanbul.

Şimşek, F. (2020). A3 türü düzensizliğe sahip betonarme bir yapının DBYBHY-2007 ve TBDY2018 esaslarina göre incelenmesi. Yüksek Lisans Tezi, İstanbul Teknik Üniversitesi Fen Bilimleri Enstitüsü, İstanbul.

TBDY, 2018. Türkiye Bina Deprem Yönetmeliği, Afet ve Acil Durum Yönetimi Başkanlığı, Ankara.

Topaktaş, M. (2019). Kolon süreksizliği bulunan betonarme bir binanın DBYBHY-2007 ve TBDY2018 esaslarına göre incelenmesi. Yüksek Lisans Tezi, İstanbul Teknik Üniversitesi Fen Bilimleri Enstitüsü, İstanbul.

Turan, G.E. (2020). 2007 ve 2018 Türkiye deprem yönetmeliklerine göre farkl döşeme sistemlerine sahip betonarme bir yapının deprem davranışlarının karşılaştırılması. Yüksek Lisans Tezi, Recep Tayyip Erdoğan Üniversitesi Fen Bilimleri Enstitüsü, Rize.

Tunç G. ve Tanfener, T. (2016). 2007 ve 2016 Türkiye Bina Deprem Yönetmeliklerinin örneklerle mukayesesi. 3.Ulusal Yapı Kongresi ve Sergisi Teknik Tasarım (ss. 153-166). Ankara.

Uçar, B. (2019). Betonarme bir hastane binasının DBYBHY 2007 ve TBDY 2018 kapsaminda deprem performansının değerlendirilmesi. Yüksek Lisans Tezi, İstanbul Teknik Üniversitesi Fen Bilimleri Enstitüsü, İstanbul.

Ulutas, H. (2019). DBYBHY (2007) ve TBDY (2018) deprem yönetmeliklerinin kesit hasar sinırları açısından kıyaslanması. Avrupa Bilim ve Teknoloji Dergisi, (17), 351-359. https://doi.org/10.31590/ejosat.620827

Yalçın, H., Gülen, L. ve Utkucu, M. (2013). Türkiye ve yakın çevresinin aktif fayları veri bankası ve deprem tehlikesinin araştırılması. Yerbilimleri, 34(3), 133-160.

Yalın, M. ve Ulutaş, H. (2021). Mevcut okul türü bir binanın deprem performansının 2007 ve 2018 deprem yönetmeliklerine göre değerlendirilmesi. Niğde Ömer Halisdemir Üniversitesi Mühendislik Bilimleri Dergisi. https://doi.org/10.28948/ngumuh.896637 